\title{
O ESPAÇO DO BRINCAR E DA CRIANÇA NA METRÓPOLE
}

Merenice Merhej ${ }^{1}$

\section{Resumo:}

Este artigo propõe-se a apresentar resultado de investigação sobre qual o espaço do brincar e das crianças na metrópole, analisando duas praças localizadas na periferia de São Paulo, no bairro do Campo Limpo, zona sudoeste. Foi utilizada a Escala de Bem Estar e Envolvimento no intuito de analisar a interação das crianças, grau de envolvimento e, sobretudo, a adequação dos equipamentos destinados a elas. A observação da pesquisa compreendeu o mês de julho de 2019, período de férias escolares. Para análise final, foram levantadas referências com base na definição de brincar como atividade de livre escolha, proposta por Huizinga, da criança como um problema social do adulto, proposta por William Corsaro e o papel das brincadeiras no desenvolvimento da criança de três a cinco anos, foco dessa investigação, sob a perspectiva de Vigotsky.

Palavras-chave: Metrópole. Criança. Brincadeiras. Corsaro. Huizinga.Vigotsky.

\section{THE CHILDREN AND PLAY SPACES IN THE METROPOLIS}

\begin{abstract}
:
This article aims at to present results of investigation about children and play spaces in the metropolis, analyzing two squares located in the suburbs of São Paulo, on the neighborhood of Campo Limpo, Zona Sudoeste of the City of São Paulo, SP, Brazil. The well-being and involvement scale (Laevers, Debruyckere, Silkens e Snoeck, 2005) was used in order to analyze the children's interaction, level of involvement and the adequacy of the equipment intended for them. The observation activities of the research were developed during-July 2019, month of school holidays in São Paulo. The analysis is based on theoretical references raised from the definition: of play as an activity of free choice, proposed by Huizinga; of the child as a social problem of the adult, proposed by William Corsaro; and the role of play in the development of children aged 3 to 5 years, the focus of this investigation, from the perspective of Vigotsky.
\end{abstract}

Key Words: Metropolis. Children. Play.

\footnotetext{
${ }^{1}$ Bacharel em Letras pela FFLCH-USP, mestre e doutoranda pela Faculdade de Educação da USP, mediadora de leituras e coordenadora de projetos culturais voltados à escola pública de ensino básico e fundamental. Em relação a este texto, foi inicialmente apresentado à Professora Dra. Tizuko Morchida Kishimoto, responsável pela disciplina Brinquedos e brincadeiras na educação infantil, oferecida pelo Programa de Pós-graduação da FEUSP, no primeiro semestre de 2019. Minha orientadora, Professora Dra. Roseli Fischmann, acompanhou o desenvolvimento deste texto e sugeriu sua publicação, com algumas alterações. Agradeço às professoras pelas sugestões, críticas e incentivo para publicar este texto. Ressalto, contudo, que qualquer erro é de total responsabilidade minha.
} 
Cadernos CERU, Série 2, Vol. 31, n. 1, jun. 2020

\section{Introdução}

O processo de urbanização na modernidade interferiu diretamente nos espaços do brincar na cidade e, mais ainda, no espaço da criança na metrópole. A cidade, ao mesmo tempo em que proporciona o convívio com o outro, também se apresenta como risco e lugar de violência (SIMMEL, 1967). As brincadeiras das crianças foram gradativamente descoladas das ruas e bairros para ambientes de intervenção direta do Estado e projetados por ele. O local de perigos, violências e perdas, que nos contos de fadas simbolizavam o Bosque, na contemporaneidade, é a própria cidade e a rua que se organizaram sob o signo da violência, emitindo um enunciado de necessidade de vigilância e controle, cristalizado na sociedade brasileira (DIAS; ESTEVES, 2017, p. 645).

No caso da cidade de São Paulo, a notória opção por carros foi iniciada a partir da década de 1930 com a instalação das primeiras revendedoras de automóveis, GM e Ford, e a idealização do "Plano de Avenidas", por Prestes Maia, que o colocou em prática ao assumir a prefeitura em 1938. Essa opção intensificou o signo das ruas violentas e dos espaços públicos como perigo constante para crianças, somando à violência urbana, a questão dos atropelamentos. A rua, então, tornou-se o espaço privilegiado para o automóvel, não para as crianças brincarem ou, mesmo, para os adultos ocuparem.

Ainda que o ambiente urbano proporcione a inter-relação com sujeitos sociais, de forma única e dinâmica, cuja diversidade é a tônica, as cidades "vêm perdendo o status de lugar vivencial" e nas últimas décadas as discussões sobre planejamento urbano apontam para a indispensabilidade de "recuperar o que foi degradado e tentar criar um novo mundo", no intuito de privilegiar a convivência e coletividade que pressupõem a vida urbana (DIAS; ESTEVES, 2017).

Essa necessidade de repensar a cidade e a reivindicação do direito à cidade intensificaram-se no século XXI; no entanto, há pouca literatura que trate do assunto focando na criança e no seu lugar na metrópole. O direito ao brincar, legislado desde a publicação do Estatuto da Criança e do Adolescente, não prevê a ocupação dos espaços públicos para além da escola. A escola tornou-se, essencialmente, o espaço privilegiado da criança e os projetos educacionais não contemplam a ocupação e o direito à cidade para as crianças.

Este trabalho procura analisar como as políticas públicas de ocupação à cidade incluem e excluem a criança pequena e pretende investigar, de maneira introdutória, qual o espaço do brincar e da criança na metrópole, a partir da observação e pesquisa qualitativa de duas praças 
Cadernos CERU, Série 2, Vol. 31, n. 1, jun. 2020

da periferia de São Paulo, na região do Campo Limpo, zona sudoeste do município.

\section{O espaço do brincar e o espaço da criança na metrópole}

Se esta rua fosse minha, eu mandava ladrilhar, não para automóvel matar gente,

mas para criança brincar.

Se esta rua fosse minha, eu não deixava derrubar.

Se cortarem todas as árvores, onde é que os pássaros vão morar?

(José Paulo Paes in: Paraíso)

O processo de industrialização e as relações com o trabalho interferiram intensamente na vida da civilização ocidental, tendo as cidades e mais recentemente as metrópoles e agora as megalópoles como fecundo objeto de estudos das diferentes áreas do conhecimento. No entanto, aparentemente, as cidades e os grandes centros urbanos excluem as crianças também na literatura sobre o tema. Aparecem, geralmente, como um detalhe, uma citação ou, na maioria das vezes, quando são as protagonistas das análises, enfatizando-se os problemas sociais das crianças. Questões como trabalho infantil, vulnerabilidade, violência nos grandes centros urbanos são assuntos recorrentes ao se tratar da criança nas sociedades contemporâneas em grandes centros urbanos.

E o brincar, as brincadeiras, as atividades simbólicas tão associadas às crianças? Embora a escola seja o espaço privilegiado da criança nos grandes centros urbanos, faz-se necessário pensar qual o espaço do brincar na metrópole fora do contexto escolar e no interior da dinâmica urbana.

\section{O brincar fora do contexto escolar}

Definir o brincar não é uma tarefa fácil e não pode ser feito de modo simplista, pois trata-se de um assunto complexo e diverso. Além da complexidade da definição, a forma como a brincadeira e o jogo são compreendidos depende também da cultura e do contexto em que está sendo analisado.

Doris Bergen (2014), ao apresentar as principais teorias sobre o brincar e as brincadeiras desde Platão até a contemporaneidade, ressalta que o jogo/as brincadeiras apesar de serem parte da experiência humana desde os primórdios, as teorias sobre "valor, significado, natureza, efeitos e influências, são bem diversificadas e até controversas" (p.9). De acordo com Bergen, 
Cadernos CERU, Série 2, Vol. 31, n. 1, jun. 2020

a brincadeira é um fenômeno que se pode observar nos animais, no comportamento das crianças humanas e também na vida dos humanos adultos e as perspectivas teóricas sobre a brincadeira apontam para quatro principais vertentes: definição e características comportamentais do que chamam brincadeira/jogo; exame das brincadeiras nos animais e seus significados; pesquisa sobre a brincadeira como fenômeno sociocultural e as características das brincadeiras e suas variedades no desenvolvimento da criança.

Ao chegar à segunda metade do século XX, entre as teorias derivadas de estudos com animais e as focadas nas características e finalidades das brincadeiras, Berger destaca as contribuições de Huizinga e a perspectiva cultural do jogo. Segundo o autor,

Numa tentativa de resumir as características formais do jogo, poderíamos considerá-lo uma atividade livre, conscientemente tomada como 'não séria' e exterior à vida habitual, mas ao mesmo tempo capaz de absorver o jogador de maneira intensa e total. (HUIZINGA, 2011, p. 16).

Neste trabalho, por se tratar de uma análise introdutória no intuito de investigar qual o espaço do brincar e da criança na cidade, fora do contexto escolar, a definição de Huizinga tem importância, em especial no que se refere à concepção de "atividade livre" e exterior à vida habitual. Para a maioria das crianças entre três e cinco anos, brincar em praças e em espaços públicos não escolares, no contexto da vida urbana, tornou-se uma atividade exterior ao seu cotidiano. Ainda que a maioria das escolas infantis possuam playgrounds parecidos aos das praças e, em alguns casos, com oferta maior de brinquedos, o contexto de ocupação de espaço e o cenário sem muros torna esta atividade mais livre e com uma possibilidade maior de escolha e autonomia da criança nas brincadeiras. Ainda que Huizinga afirme que a brincadeira tem um fim em si mesmo e não se ocupe sobre o desenvolvimento e aprendizado no jogo/brincadeira, a definição de que a brincadeira é essencialmente uma atividade livre e de livre escolha é compartilhada por autores que tratam especificamente da brincadeira como forma de aprendizado e desenvolvimento da criança.

Embora os estudos sobre a importância da brincadeira no desenvolvimento e aprendizado da criança tenham sido aprofundados no século XX (BERGER, 2014) e o brincar seja a atividade mais importante na educação infantil, na prática e no contexto escolar brasileiro e paulistano, a livre escolha da criança nem sempre é respeitada e o brincar da criança, muitas vezes, é confundido com atividades impostas pelo educador, que fogem ao modelo expositivo de aula. Apesar da importância reconhecida do brincar para a infância, esse direito é negligenciado mesmo nos espaços privilegiados para que a atividade aconteça, como é a escola de educação infantil. 
Cadernos CERU, Série 2, Vol. 31, n. 1, jun. 2020

De acordo com Vigotsky (2000), é entre os três e cinco anos que a criança se envolve nas situações imaginárias e essas situações chamamos de brincadeiras. O simbólico nesta fase tem uma influência muito grande no desenvolvimento e aprendizado da criança dessa faixa etária. Ainda que os locais públicos se apresentem adequados para crianças dessa faixa etária, na maioria das vezes é a atividade motora o foco dos espaços ao ar livre, sem que haja incentivo para atividades imaginativas. A ligação entre imaginação e criança é tão forte que, aparentemente, se acredita que essas atividades não precisam ser incentivadas ou estimuladas. Segundo Vigotsky (2000), a brincadeira simbólica tem uma enorme influência no desenvolvimento da criança, pois, para o autor, a criação de situações imaginárias ajuda a criança a guiar seu comportamento não apenas para resolver aquela situação imediata na brincadeira, mas na compreensão do significado daquela situação (p.148).

No caso dos espaços públicos ao ar livre, pouco se incentiva a brincadeira simbólica e se observa uma associação mais direta com as atividades motoras, do que com qualquer outra coisa. Nesse sentido, as atividades simbólicas e de livre escolha da criança são pouco incentivadas, tanto no âmbito da brincadeira em espaço escolar quanto nos espaços ao ar livre. Ainda que as brincadeiras simbólicas não necessitem de um contexto ou espaço específico para serem desenvolvidas, o planejamento urbano poderia incluir estímulos a esse tipo de atividade, sobretudo para a criança pequena de três a cinco anos, faixa etária em que o simbólico é muito importante para o desenvolvimento da criança.

\section{A periferia da metrópole paulistana}

Aqui não vejo nenhum clube poliesportivo

Pra molecada frequentar nenhum incentivo

O investimento no lazer é muito escasso

O centro comunitário é um fracasso

(Racionais MC's in: Fim de semana no Parque).

Antes de aprofundar nos espaços analisados neste trabalho, faz-se necessária uma breve reconstituição histórica da urbanização da cidade de São Paulo e o fenômeno de periferização da metrópole.

$\mathrm{O}$ crescimento populacional, como em toda metrópole, está ligado à industrialização e sua expansão territorial (LEFEBRE, 2011). Porém, segundo o autor,

Existe, historicamente, um choque violento entre a realidade urbana e a realidade industrial. Quanto à complexidade do processo, ela se revela cada vez mais difícil de ser apreendida, tanto mais que a industrialização não produz apenas empresas (operários e chefes de empresas), mas sim estabelecimentos diversos, centros bancários e financeiros, técnicos e políticos. (LEFEBRVE, 2011, p. 17). 
Cadernos CERU, Série 2, Vol. 31, n. 1, jun. 2020

No início do século XX a industrialização na cidade foi impulsionada e propiciada pela eletricidade trazida pela Light, de origem canadense, impulsionando a transformação da paisagem de São Paulo, mas foi a partir das décadas de 1920 e 1930 que a formação do polo industrial se consolidou e os arranha-céus passaram a fazer parte da cidade, com o processo de verticalização (MONBEIG, 1957/2004).

O processo de transformação da cidade vai se intensificando, assim como a segregação urbana, como aponta Abrahão:

As desigualdades socioeconômicas implícitas na segregação urbana e, que definem, a seleção das prioridades responsáveis pela organização de seu território, produziu, em consequência, um sistema estrutural de vias também desigual em cada um dos vários quadrantes da cidade, focado na redução do tempo de deslocamento do automóvel particular.

A prioridade na cidade de São Paulo à circulação sobre pneus, foi claramente sinalizada e posta em prática a partir do Plano de Avenidas de Prestes Maia, publicado em 1930 e executado uma década depois, em seu primeiro mandato como prefeito (1938-1945). (ABRAHÃO, 2011, p.74).

A opção por carros e o choque entre os fenômenos de urbanização e industrialização podem ser observados no processo de expansão da cidade de São Paulo. Ao contrário de muitos centros urbanos, a expansão metropolitana de São Paulo, sobretudo a partir dos anos de 1980, está ligada à sua forma viária que permite o descolamento de áreas distantes aos grandes centros financeiros, promovendo uma periferização e a existência de várias cidadesdormitório na região metropolitana (MEYER; GROSTEIN; BIDERMAN, 2013). Para Meyer, Grostein e Biderman, não há uma relação direta para expansão física metropolitana entre "o dinamismo econômico metropolitano, a concentração populacional e a expansão da área urbana" (p.48). A expansão ocorreu e continua ocorrendo tanto em municípios com intensa atividade econômica quanto em outros, ocasionando um padrão periférico de expansão territorial, criando municípios-dormitório, bem como uma extensa área periférica dentro da cidade de São Paulo. O crescimento urbano das periferias ocorreu de forma distinta do "pautado pelas teorias tradicionais"; mesmo que de forma não planejada, essas áreas viabilizaram-se "pelos investimentos públicos feitos de maneira assistemática" (p.48).

As áreas periféricas, ainda hoje, apesar de a década de 1970 se caracterizar pelo início da prática do planejamento público urbano, ainda padece desses investimentos feitos de maneira assistemática e não planejados. Com o crescimento da metrópole, as ruas das periferias acompanharam a tendência central e do poder público, na opção por carros, iniciada na década de 1930, como já mencionado anteriormente neste trabalho.

O investimento em áreas de lazer nessas regiões é muito escasso e, assim como nos demais bairros da metrópole, as áreas destinadas às crianças pequenas, resumem-se às poucas praças com brinquedos voltados a elas, reproduzindo um padrão no planejamento urbano da metrópole que privilegia o trabalho e o universo adulto.

\section{A criança, o brincar e a metrópole}

Quando falamos em metrópole, a imagem recorrente é o cenário tipicamente urbano de 
Cadernos CERU, Série 2, Vol. 31, n. 1, jun. 2020

prédios altíssimos, avenidas movimentadas, pessoas com pressa ou em transportes públicos lotados, tráfego intenso e pessoas indo para ou voltando do trabalho. Raramente, sendo otimista, a imagem de uma criança compõe o cenário urbano, a não ser em contextos de desvio do olhar. A criança está, quase sempre, fora do quadro urbano e, quando aparece, é em situação de vulnerabilidade ou de trabalho.

Diante deste cenário, a criança, então, é vista como um problema social, como aponta William Corsaro;

Nos Estados Unidos e em muitas outras sociedades ocidentais, passamos a ver as crianças e os problemas sociais de duas formas: crianças como problemas sociais e problemas sociais das crianças. Enxergar as crianças como problemas sociais acontece de várias formas. A primeira se relaciona com o entendimento das crianças como o que Penelope chamou de grupo externo. Com essa expressão Leach quer dizer que as crianças não são vistas como adultos, mas como inferiores e não merecedoras do mesmo respeito atribuído aos adultos (1994, p.204). Dessa forma, com frequência as crianças são percebidas como uma chateação, uma perturbação à respeitável vida adulta. (CORSARO, 2017, p. 251).

Embora o autor tome como exemplo os EUA, podemos notar uma crescente discriminação da criança na sociedade contemporânea, também no Brasil, principalmente em São Paulo. Movimentos em restaurantes como o Children Free em que crianças não são bem vindas, tornaram-se cada vez mais comuns nas cidades. Há uma supressão da criança no convívio urbano que se reflete nas políticas públicas de organização da paisagem urbana. Por serem vistas como inferiores e não merecedoras do mesmo respeito que o adulto, as crianças são subestimadas e isso pode ser percebido não somente nas organizações urbanísticas, mas também em pequenos detalhes, como a escolha de materiais e brinquedos para educação infantil.

Corsaro aponta também para a grande preocupação e cuidado a respeito da sua segurança, como uma outra forma de ver a criança como um problema social. Ainda que a sociedade estadunidense seja sua fonte de exemplos, no Brasil, a diferença se dá mais nos exemplos dos medos que no signo dos centros urbanos como violentos. Durante a realização desta pesquisa, o medo da violência, das pessoas usando drogas nas praças e da pouca segurança que os brinquedos apresentavam nas praças esteve presente nos discursos dos responsáveis.

O discurso das ruas perigosas e o signo de violência atribuído aos centros urbanos excluíram a criança ainda mais do convívio adulto. No Brasil, a cristalização das ruas como escola de malandragem inicia-se com o processo de industrialização que, no caso de São Paulo, se deu durante o início do século XX. Com os operários trabalhando quase em tempo integral 
Cadernos CERU, Série 2, Vol. 31, n. 1, jun. 2020

e o Estado não oferecendo acesso universal à escola, as crianças ficavam nas ruas do centro da cidade, atrás de bicos ou perambulando enquanto os pais estavam na fábrica (SANTOS, 2004). Segundo o autor, para sanar o problema social que se tornaram as crianças nas ruas, associadas à criminalidade, iniciou-se uma intensa campanha na mídia, nas primeiras décadas do século XX na defesa do trabalho infantil, como formação de caráter e meio de tirar as crianças das ruas. Com a proibição do trabalho infantil, o espaço escolar passou a ser reivindicado para a criança na metrópole paulistana, cobrando do poder público ações no sentido de tornar universal o acesso à escola. É possível observar nesses discursos cristalizados em nossa sociedade, como afirmou Corsaro (2001), a criança aparecendo como um problema social e o problema social da criança. Essas formas de olhar a criança interferem intimamente no planejamento urbano e nas políticas públicas voltadas às crianças, associadas essencialmente ao espaço escolar, fora do contexto e da dinâmica urbana e isoladas do cotidiano dos adultos.

Não é difícil, portanto, compreender o motivo da negligência dos projetos paisagistas às necessidades infantis, bem como a ausência do investimento público em áreas que valorizem e incentivem a presença da criança pequena, privilegiando as brincadeiras simbólicas, não apenas motoras.

Essa negligência se agrava quando a área a ser analisada se localiza na periferia da cidade. A ausência de planejamento urbano nessas áreas e os investimentos públicos feitos de forma assistemática aumentam os problemas das praças e da manutenção dos brinquedos e aparelhos instalados nelas. Transformações contínuas podem ser observadas nesses espaços, em que a manutenção é extremamente esporádica.

Desse modo, se a criança dos bairros de classe média alta já é negligenciada no planejamento urbano como um todo, a criança dos bairros periféricos fica exposta a brinquedos enferrujados e áreas sem manutenção da área verde e iluminação dos locais, o que afasta os responsáveis, preocupados com a segurança.

\section{Metodologia}

Este trabalho utiliza a escala de Bem Estar e Envolvimento, adaptada à praça pública, para analisar o envolvimento da criança de três a cinco anos nesses espaços. Foram observadas seis crianças ao todo, em três dias de observação, caracterizando dois finais de semana, no período entre 23 a 14 de julho de 2019. Só foi possível observar em dois finais de semana, por causa do clima chuvoso e frio no período da pesquisa. As observações foram feitas nos finais de semana, porque durante a semana não havia crianças, em nenhuma das praças. 
Cadernos CERU, Série 2, Vol. 31, n. 1, jun. 2020

A escolha da escala para análise qualitativa dos espaços deve-se à possibilidade de observar o planejamento urbanístico dos espaços a partir do uso e envolvimento da criança, podendo demonstrar o quanto esses espaços incluem/excluem a criança pequena na disposição, organização e escolha dos seus equipamentos e projetos arquitetônicos.

Os indicadores da escala de Bem Estar e Envolvimento não foram alterados, seguindo a ordem:

- Concentração

- $\quad$ Energia

- $\quad$ Complexidade

- $\quad$ Expressão facial e postura

- Persistência

- $\quad$ Precisão

- $\quad$ Tempo de reação

- $\quad$ Linguagem

- Satisfação.

O relatório das observações estão no Anexo 1 deste trabalho, em que foi descrita detalhadamente a interação das crianças com os brinquedos, seus pares e as brincadeiras desenvolvidas por elas.

A pesquisa foi toda feita por meio de observação, sem uso de filmagem das crianças, pois foram encontrados problemas para autorização de vários pais, nos dias em que foi feita a pesquisa. $^{2}$

\footnotetext{
${ }^{2}$ Alguns pais alegaram divergências políticas, pois não queriam que suas fotos e de seus filhos fossem utilizados em matéria da "esquerda", mesmo eu explicando que tratava-se de um trabalho acadêmico, para disciplina de doutorado e que não seria publicado em veículo de comunicação de massa. O fato de me apresentar como pesquisadora da USP já me colocava no lugar de "pessoa de esquerda" para estes responsáveis. Deste modo, as observações foram feitas apenas com crianças autorizadas, mas sob a condição de não divulgação de nomes, apenas idade. Ressalto que em nenhum momento mencionei posicionamento político, apenas apresentei o teor do trabalho e o motivo da pesquisa. Detalho este problema, pois este tipo de tensão para autorização de pesquisa com crianças, repetiu-se no exercício de sala de aula proposto na disciplina, quando tentei autorização para pesquisar as crianças brincando em escola de educação infantil, em especial as conveniadas e acredito ser importante relatar que o discurso do atual governo contra a pesquisa científica está ganhando força na sociedade.
} 
Cadernos CERU, Série 2, Vol. 31, n. 1, jun. 2020

As fotos deste trabalho são para descrição das praças, pois também não foi obtida autorização para utilização das fotos com as crianças nos aparelhos. ${ }^{1}$

Ao todo, foram analisadas cinco crianças em cada praça, em três dias de observação em diferentes dias em cada uma delas. Foram priorizados os finais de semana à tarde e as sextas feiras, também no período da tarde, entre os dias 22 de junho e 14 de julho. Em alguns finais de semana deste período, não foi possível fazer a pesquisa por causa do clima chuvoso.

\section{Descrição das praças:}

As praças ficam localizadas nos bairros do Jardim Catanduva, Jardim Novo Oriente/ Parque Regina/Parque Arariba.

\section{Praça Alexandre Vanucci:}

A praça, inaugurada em 1991, localiza-se à Rua Berco Udler, em frente à EMEF Coronel Palimércio de Rezende e já passou por diversas transformações. No ano de 2018, foi reformada com equipamentos de ginásticas, utilizados, essencialmente no período diurno, por idosos, que fazem caminhada, num projeto da UBS do mesmo bairro.

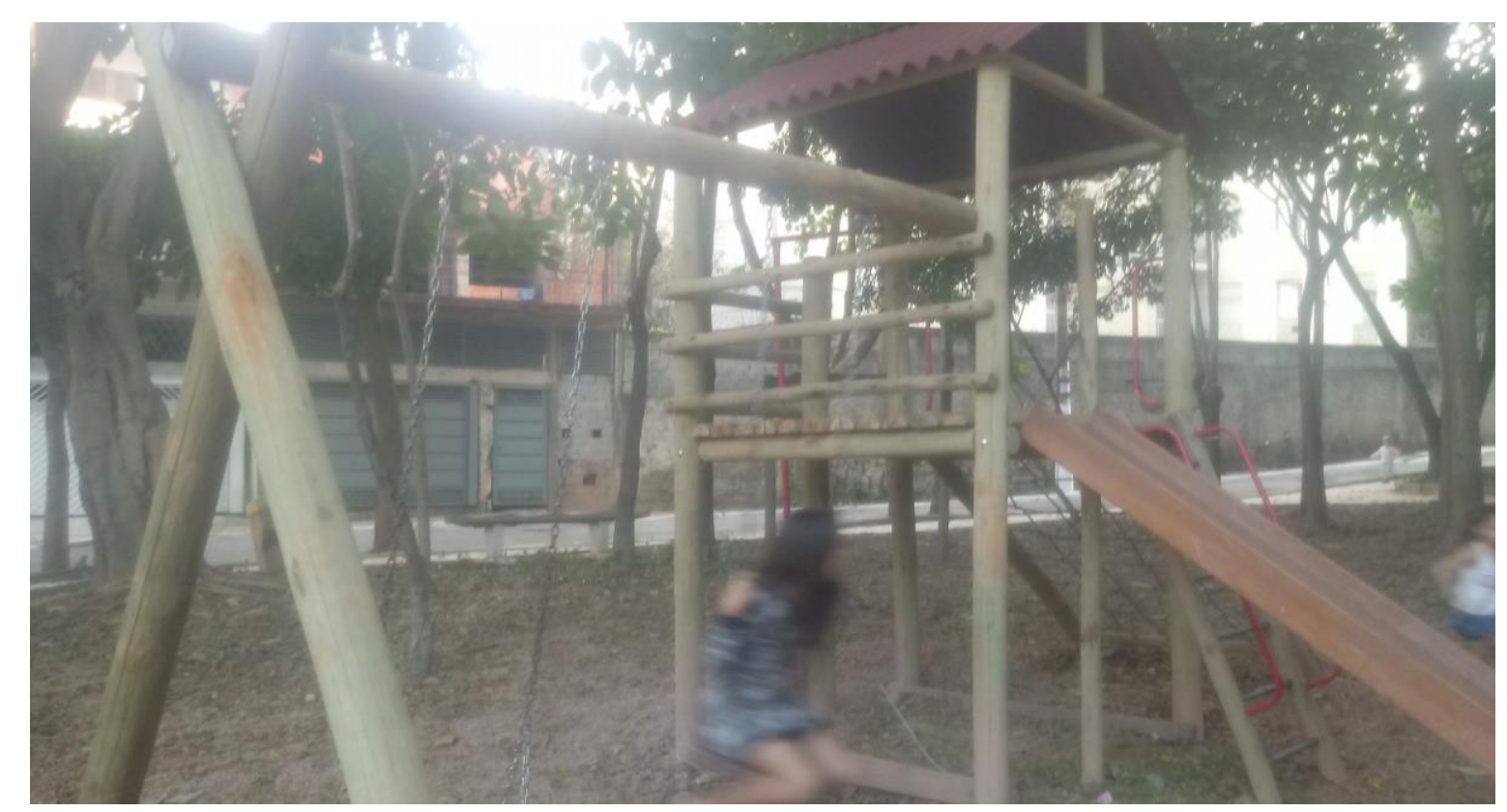

(acervo pessoal, julho/2019)

Figura 1 - Área da Praça Alexandre Vanucci voltada às crianças

Pouco frequentada por crianças, a presença delas é mais visível nos finais de semana, 
Cadernos CERU, Série 2, Vol. 31, n. 1, jun. 2020

ainda assim crianças com mais de nove anos. O período da tarde é o mais frequentado, entre $14 \mathrm{~h}$ e $16 \mathrm{~h}$, e crianças de três a cinco são vistas quando acompanhada dos pais. Durante o período da pesquisa, não foram observados pais ou mães acompanhando crianças entre três e cinco anos que não estivessem com outro filho maior nesta praça. As condições e atrativos para criança são poucos e, quando se trata da faixa etária analisada, são quase inexistentes.

Nessa praça foram observadas três crianças. É importante ressaltar que, ainda que uma parte da pesquisa tenha sido feito em período de férias, o clima frio pode ter sido um fator importante para a pouca frequência das crianças pequenas nos dias observados. No entanto, para afirmar com absoluta certeza, seria necessário mais tempo de observação, em diferentes períodos.

Outro fator importante na descrição desta praça é que, por estar localizada em local de pouca circulação, iluminação e em local exclusivamente residencial, a praça é evitada pelos pais das crianças, pois se tornou ponto de uso de drogas por jovens e adolescentes. A pouca visibilidade do local e falta de manutenção da área verde contribui para a intensificação do signo de violência do espaço público.

\section{Praça Jardim Novo Oriente/Parque Regina/Parque Arariba}

A praça do Jardim Novo Oriente está localizada à Rua Padre Adolfo Kolping e se caracteriza por seu comprimento. Em princípio, era apenas uma extensão de área não pavimentada, separando as duas mãos da Avenida. Entre os anos de 2007 e 2009, tornou-se uma ciclovia que desembocava no Parque Arariba, acesso à Rua Carlos Caldeira Filho. No ano de 2013, foram criadas ciclo-faixas nas duas mãos e a extensão de terra transformada em praça, com uma grande área verde, quadra para skate, brinquedos infantis e também os aparelhos de ginásticas, política pública intensificada neste período e mantida pela administração atual. 
Cadernos CERU, Série 2, Vol. 31, n. 1, jun. 2020

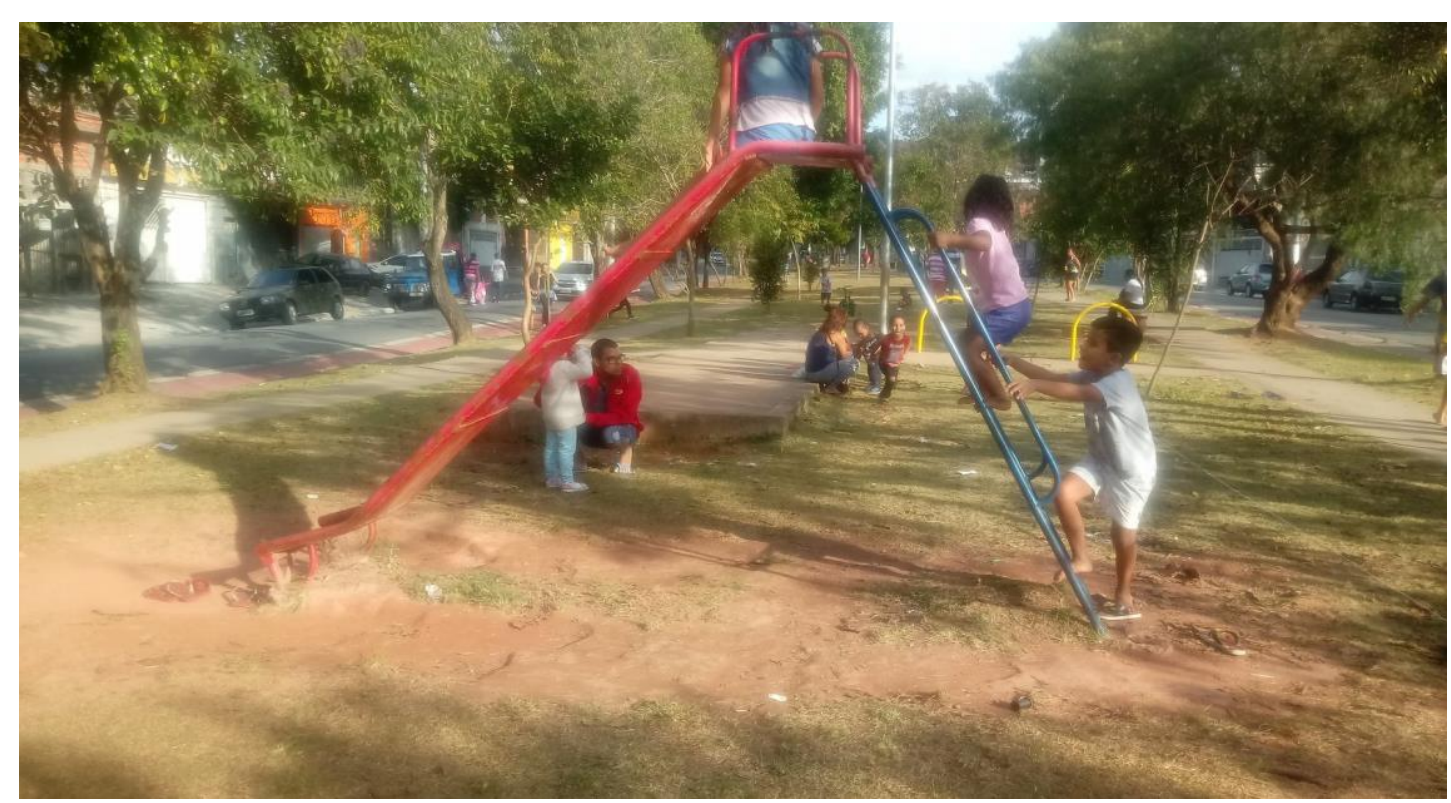

(acervo pessoal, julho/2019)

Figura 2 - Área para crianças da Praça do Jardim Novo Oriente

A praça é mais movimentada, por estar localizada numa avenida, contudo, a presença de crianças pequenas em dias de semana é, também, quase nula, ainda que aos finais de semana seja possível observar algumas brincando. Os brinquedos para crianças apresentam maior atratividade, são coloridos, mas a manutenção deixa a desejar. Faltam uma gangorra e dois balanços e o banco é feito de pneu, sem tratamento e a maior parte do espaço é de concreto. A antiga ciclovia é hoje usada para caminhadas, em especial por adultos, e as crianças maiores, entre cinco e nove anos, utilizam para andar de patins e bicicleta. Algumas crianças menores também andam de bicicleta e velocípede, mas com menor frequência.

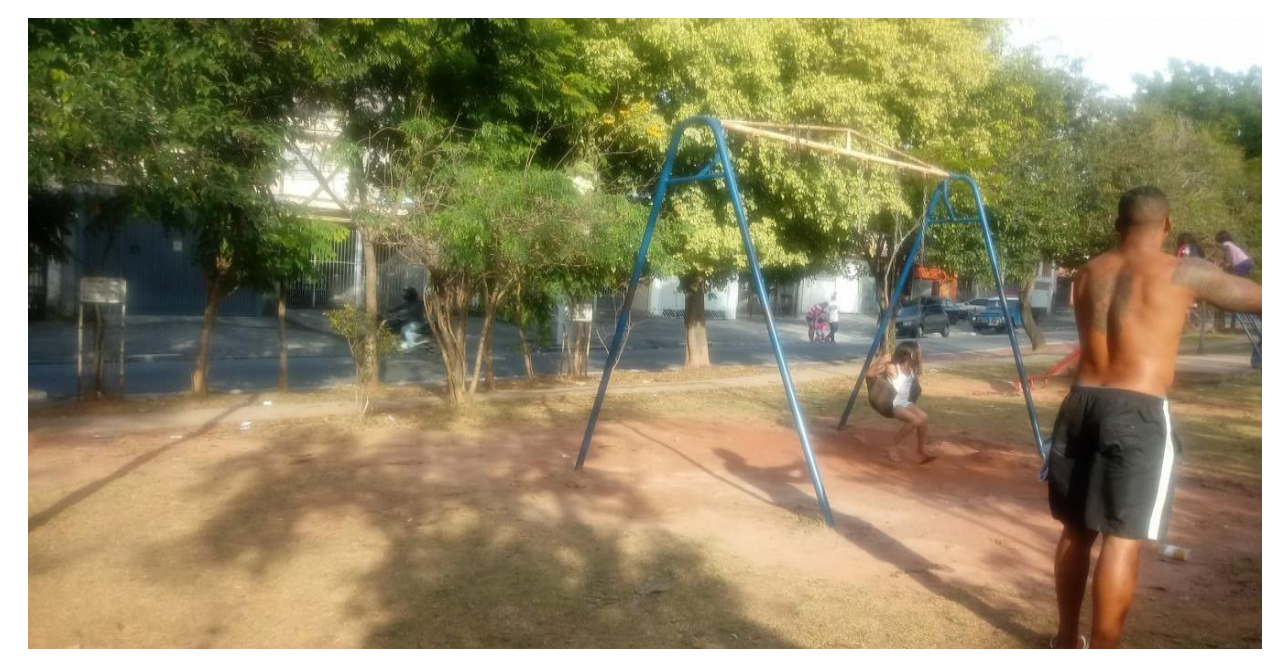

(acervo pessoal, junho/2019) 
Cadernos CERU, Série 2, Vol. 31, n. 1, jun. 2020

Figura 3- Balanço sem manutenção da Praça do Jardim Novo Oriente

\section{Análise da observação}

A partir da observação e da descrição apresentada no anexo 1, foi possível levantar algumas questões sobre o uso dos equipamentos das praças pela criança pequena, de três a cinco anos.

O nível de Bem Estar e Envolvimento foi baixo, apresentando pouca variação entre os níveis 1 e 2, com maior envolvimento na Praça Alexandre Vanucci:

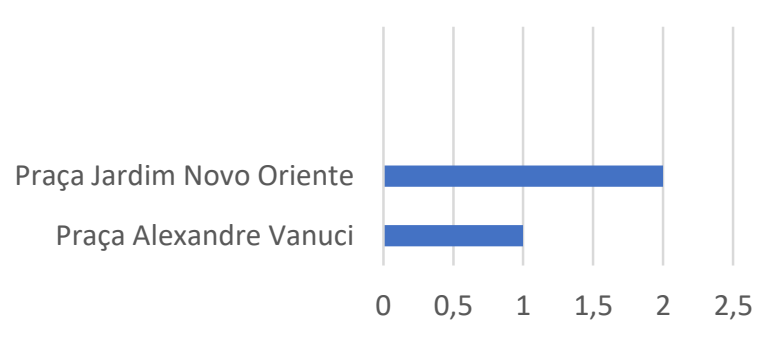

Escala de Envolvimento

\section{Gráfico 1 - Nível de Envolvimento}

Na Praça Alexandre Vanucci foi possível observar um pouco mais de envolvimento das crianças, muito mais pelo espaço em que está localizada, com pouca circulação de carros e com uma extensa área verde, aumentando a complexidade das atividades motoras, como correr, subir morro e árvores mais baixas que possibilitam a subida também pela criança pequena, do que pelos brinquedos oferecidos pelo poder público.

Embora a praça possua uma área extensa em que o relevo natural propicie o desenvolvimento de brincadeiras com complexidade e desenvolvimento de atividades simbólicas, há pouco incentivo para que isso ocorra, não só pelo projeto arquitetônico, mas também pelos responsáveis que repreendem as crianças quando resolvem sair da área construída, como na descrição do relatório (anexo I) do dia 23 de junho:

A criança desiste do escorrega e tenta subir o morro da praça, quando é fortemente repreendida pelo responsável, que diz que é perigoso ir até lá. Perde o interesse pelos brinquedos na área infantil e começa a correr em volta da mesa. Novamente se afasta da área específica para crianças e direciona-se à árvore, na tentativa de subir nela, porém, é novamente repreendida pelo responsável que aponta que ela só pode permanecer próxima aos brinquedos do parquinho. (Anexo I, 23 de junho, 2019, 13h00-13h02). 
Cadernos CERU, Série 2, Vol. 31, n. 1, jun. 2020

A reação do responsável demonstra a preocupação excessiva pela segurança da criança, apontada por Corsaro (2017), culpabilizando-a por querer brincar fora do espaço, teoricamente, limitado a ela. A tentativa de prevenir acidentes é somada ao discurso de violência urbana, no momento em que a criança se dirige para área mais afastada.

A interação com os brinquedos é a principal atividade na praça, no entanto, aqueles específicos para criança acabam sendo impostos pelos adultos, não caracterizando uma escolha livre das crianças, como foi possível relatar em todas as crianças observadas nas duas praças. Em especial na Praça Alexandre Vanucci, reformada recentemente, as crianças se dirigiam de forma sistemática aos equipamentos de ginásticas, que, além de serem mais atrativos visualmente, são ofertados em maior quantidade, já que para criança só há um equipamento multifuncional com apenas dois balanços. A escolha desses equipamentos, contudo, às vezes terminava em frustração, como na observação do dia 13 de julho nessa mesma praça, em que a criança, por não conseguir subir no equipamento, começou a chorar e se desinteressou quase que totalmente pela praça.

Na praça do Jardim Novo Oriente, como a oferta dos brinquedos é pequena e a maioria está quebrada, as crianças preferem brincar correndo ou soltando pipas. Geralmente a interação é com o responsável ou irmão mais velho, como descrito no relatório do dia 22 de junho (Anexo I):

A criança tenta brincar no balanço, mas há uma fila grande, com crianças maiores para usar. Aguarda na fila olhando para o irmão mais velho, 8 anos, empinando pipa. Desiste, frustrada. Vai até a mãe, sentada num dos bancos da praça e fica ali, um entre o choro e o resmungo.

(...) Se aproxima do irmão que a deixa manusear a linha da pipa que está empinando. (Anexo 1- 22 de junho, 2019, 15h20 -15h22; 15h22$15 \mathrm{~h} 24)$.

Os exemplos aqui descritos repetem-se com a maioria das crianças observadas. Ainda que os espaços possuam condições de acolher as crianças pequenas e poderia, inclusive, haver brinquedos em que as atividades simbólicas, ideais para as crianças dessa faixa etária, fossem amplamente desenvolvidas, as praças apresentam uma disputa territorial entre adultos, idosos e crianças maiores, fazendo com que as crianças pequenas, e também os idosos, se tornem um problema social, sendo excluídos e segregados em horários específicos, ou até mesmo impedidos de brincar, no caso das crianças pequenas.

Chama a atenção o fato de as crianças estarem expostas a acidentes nessas áreas, devido 
Cadernos CERU, Série 2, Vol. 31, n. 1, jun. 2020

a equipamentos em mal estado, em alguns casos enferrujados ou mesmo, no caso dos equipamentos para ginástica, inapropriados às vezes até para os adultos, pois são padronizados, negligenciando o fato de que as pessoas têm altura e corpo diferentes. No entanto, a preocupação maior é sempre com a área verde, as árvores e o afastar da criança da proximidade do adulto responsável ou de um irmão maior. É como se a simples proximidade do responsável pudesse evitar acidentes ou alguma violência social cristalizada nos enunciados sobre as cidades, ruas e as praças da periferia.

Além da interação dos responsáveis, o baixo nível de envolvimento das crianças nesses espaços se dá pela pouca complexidade das brincadeiras, que privilegiam apenas as atividades motoras e o não incentivo da cultura de pares. Cada criança brincava com seus responsáveis, ou irmãos. Não houve, nos dias pesquisados, uma interação entre as crianças e os pais que não se conheciam previamente nessas áreas. Na praça do Jardim Novo Oriente, os pais que se conheciam, estavam sentados no mesmo banco. Como na praça Alexandre Vanuci há mesas e cadeiras, os responsáveis que se conheciam se reuniam em torno das mesas. Durante o período da pesquisa, não foi observado interação entre desconhecidos, adultos responsáveis ou crianças.

Ainda que o espaço não as privilegie ou mesmo haja pouco envolvimento com os brinquedos disponibilizados para crianças nessas praças, as crianças pequenas mostraram-se persistentes na tentativa de interagir com o espaço e os brinquedos, perdendo o interesse muito mais por inadequação dos equipamentos ou problemas espaciais, como no caso da criança de bicicleta, na praça do Jardim Novo Oriente (Anexo I, 22 de junho, 16h), em que ela desiste de andar ali e pede para o pai levá-la ao posto de gasolina, próximo à praça, para poder andar de bicicleta sem ter que disputar espaços com outras crianças e adultos.

Os problemas apresentados confirmam, dentro da realidade brasileira, a análise de Corsaro (2011) sobre a criança como um problema social e a síndrome do bicho papão, em que os cuidados em demasia acabam culpabilizando a criança, muito mais que a sociedade como um todo (p.251). Há também um dado interessante, sobre a interação das crianças entre si, o que o autor chama de "reprodução interpretativa da criança", que nesta pesquisa mostrou-se reproduzir uma dinâmica típica das grandes cidades que, embora dividindo o mesmo espaço, não ocorre interação entre os desconhecidos. A cidade privilegia encontros, porém esses encontros não acontecem de maneira espontânea, há apenas a divisão e, neste caso específico da praça, disputa de espaços. O convívio dá-se por meio de grupos que se conhecem previamente ou de forma individual, entre a criança e o responsável que a acompanha. 
Cadernos CERU, Série 2, Vol. 31, n. 1, jun. 2020

A exclusão da criança nos projetos urbanísticos de bairros da periferia, caso analisado neste trabalho, aponta para uma cidade cada vez mais hostil às crianças pequenas, hostilidade essa disfarçada de signo de proteção, intensificando a simbologia de violência urbana nos espaços públicos, mas que na realidade encara a criança como um problema social, que atrapalha a vida adulta.

\section{Conclusão}

Este trabalho procurou de forma introdutória analisar a interação da criança pequena, em especial de três a cinco anos, com espaços públicos fora do contexto escolar, no intuito de investigar qual o espaço da criança e do brincar na metrópole. Apesar da análise se concentrar em duas praças localizadas na periferia de São Paulo, Zona Sudoeste do município, o padrão arquitetônico destas é repetido em quase todas as praças da região do Campo Limpo e outros bairros da zona sul da cidade. Em algumas delas, nem brinquedos para crianças existem, apenas os aparelhos de ginástica, constituídos muito mais como uma política de saúde pública, que de lazer.

Com base nos dados levantados na pesquisa qualitativa, foi observada a inadequação dos brinquedos para as crianças pequenas, bem como a falta de manutenção destes ou a pouca atratividade que possuem. Enquanto os equipamentos possuem cores saturadas que chamam a atenção das crianças, na maioria das vezes os brinquedos destinados à criança são de madeira e não coloridos, com um design pouco atrativo.

Seria necessário um tempo maior de observação, em mais espaços públicos fora do contexto escolar, para poder afirmar algo sobre a metrópole como um todo. No entanto, a revisão bibliográfica aqui apresentada e os dados descritos no relatório de observação, permitem concluir sobre a exclusão da criança pequena no projeto urbanístico dessas praças, bem como o baixo investimento do poder público na garantia do direito ao brincar das crianças, negligenciado também nas escolas de educação infantil.

A escolha da criança é constantemente mediada pelo adulto, quando não é cerceada, interferindo no conceito de brincadeira como uma livre escolha da criança, que na maioria das vezes é direcionada pelos responsáveis. Essa constante preocupação com as crianças caracteriza-se por uma tentativa dos adultos de domesticá-las, o que, consequentemente, acaba por culpabilizar a criança por tentar defender seu direito de brincar.

O menosprezo à criança pelo poder público pôde ser observado na não utilização dos espaços de forma a acolher melhor a criança pequena, que poderia encontrar nessas praças um 
Cadernos CERU, Série 2, Vol. 31, n. 1, jun. 2020

lugar de vivência mais prazerosa e de aprendizado, caso o projeto urbanístico contemplasse brincadeiras simbólicas e utilizasse a complexidade do relevo natural para criar trilhas que incentivassem esse tipo de brincadeira. Além da negligência no projeto, alia-se o fato de o investimento público nas periferias ser feito, como demonstra a história do crescimento metropolitano de São Paulo, de forma assistemática, com pouca manutenção e mudando conforme o gestor de turno, sem qualquer respeito à população. Vale observar que isso se reflete também nos projetos educacionais, pois, apesar de a legislação educacional no Brasil garantir o direito ao brincar da criança, a realidade escolar não acompanha a legislação brasileira e, também, os equipamentos e os espaços em educação infantil mostram-se, na maioria das vezes, inadequados.

A pesquisa, portanto, responde à pergunta sobre qual o espaço do brincar e da criança na metrópole sem a afirmação de que seja nenhum, pois as crianças estão brincando, ou tentando brincar na metrópole, mas infelizmente na prática, o direito ao brincar ainda não foi conquistado de forma plena por elas, ficando a cargo, essencialmente da escola. Fora do contexto escolar, a criança pequena não é privilegiada nos espaços ao ar livre e seu direito à cidade limita-se às decisões do adulto responsável e aos espaços de vigilância fechados.

\section{Referências bibliográficas}

ABRAHÃO, S. Espaço público na São Paulo do século XXI: perspectivas, 2011. In: http://www.usjt.br/arq.urb/numero_06/arqurb6_04_artigo_04_sergio_abrahao.pdf Acesso em: 10 jul. 2019.

BERGEN, D. The foundation of play. In: BROOKER, L.; BLAISE, M.; EDWARDS, S. The SAGE Handbook of Play and Learning in Early Childhood. Los Angeles: SAGE Publishing, 2014. p. 9-21.

CORSARO, W. Sociologia da Infância. Porto Alegre: Artmed, 2011.

DIAS, M.S; ESTEVES, M. O espaço público e o lúdico como estratégias de planejamento urbano humano em: Copenhague, Barcelona, Medellín e Curitiba, 2017. In: https://www.scielo.br/pdf/cm/v19n39/2236-9996-cm-19-39-0635.pdf Acesso em: 17 de junho de 2020.

HUIZINGA, J. Homo Ludens. São Paulo: Perspectiva, 2011.

LEFEBVRE, H. O direito à cidade. São Paulo: Centauro, 2011.

MEYER R.M; GROSTEIN, M.D; BIDERMAN, C. São Paulo metrópole. São Paulo: Edusp, 2013.

MONBEIG, P. O crescimento da cidade de São Paulo. In: SZMRECASANY, T. (Org.). História econômica da cidade de São Paulo. São Paulo: Globo, 2004. 
Cadernos CERU, Série 2, Vol. 31, n. 1, jun. 2020

MOURA, E.B. B. de. Crianças operárias na recém industrializada São Paulo in: PRIORE, M.D.(Org.). História das Crianças no Brasil. Porto Alegre: Contexto, 2004. p 259-288.

PAES, J.P. Poemas para brincar. São Paulo: Ática, 2008.

RACIONAIS MC'S. Fim de semana no parque in: Raio X Brasil. São Paulo: Atelier Studio, 1993.

SANTOS, M. A. C. Criança e criminalidade no início do século In: PRIORE, M. D.(Org.). História das Crianças no Brasil. Porto Alegre: Contexto, 2004, p. 210-230.

VIGOTSKY, L. S. El papel de juego en el desarollo del niño. In: VIGOTSKY, L. S. El desarrollo de los processos psicológicos superiores. Barcelona: Crítica, 2000. p. 141-158. 
Cadernos CERU, Série 2, Vol. 31, n. 1, jun. 2020

\section{ANEXO I - FICHAS DE OBSERVAÇÃO}

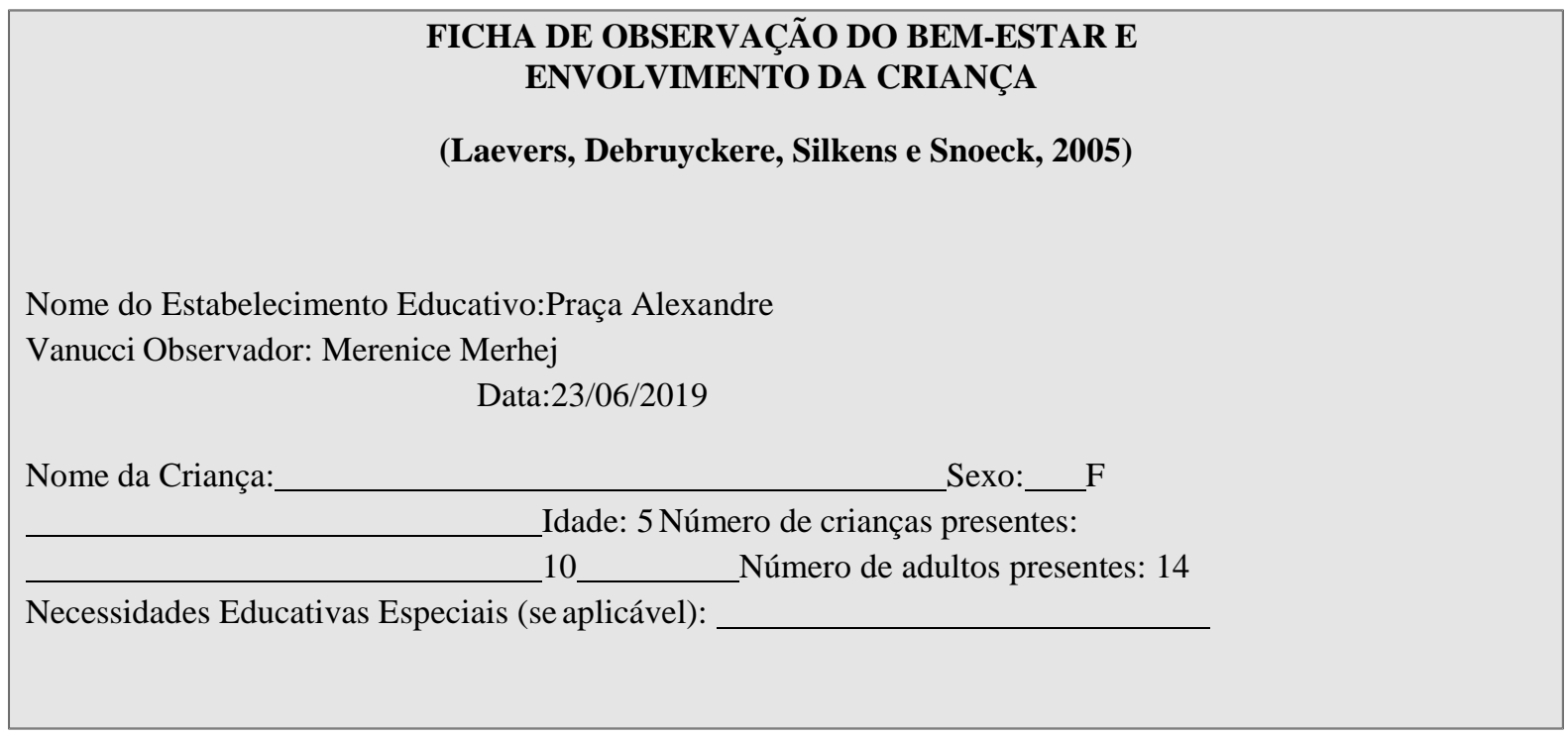

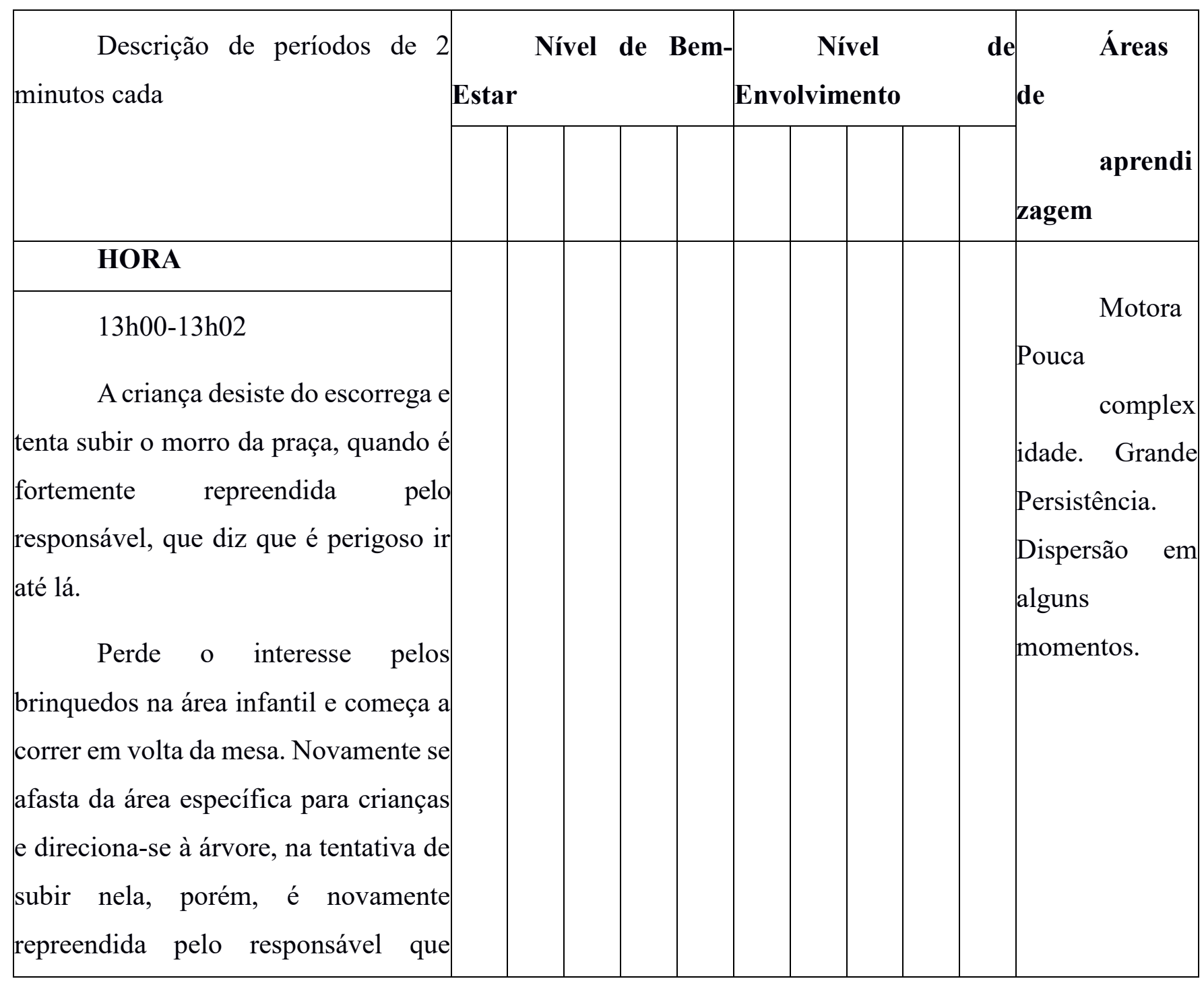


Cadernos CERU, Série 2, Vol. 31, n. 1, jun. 2020

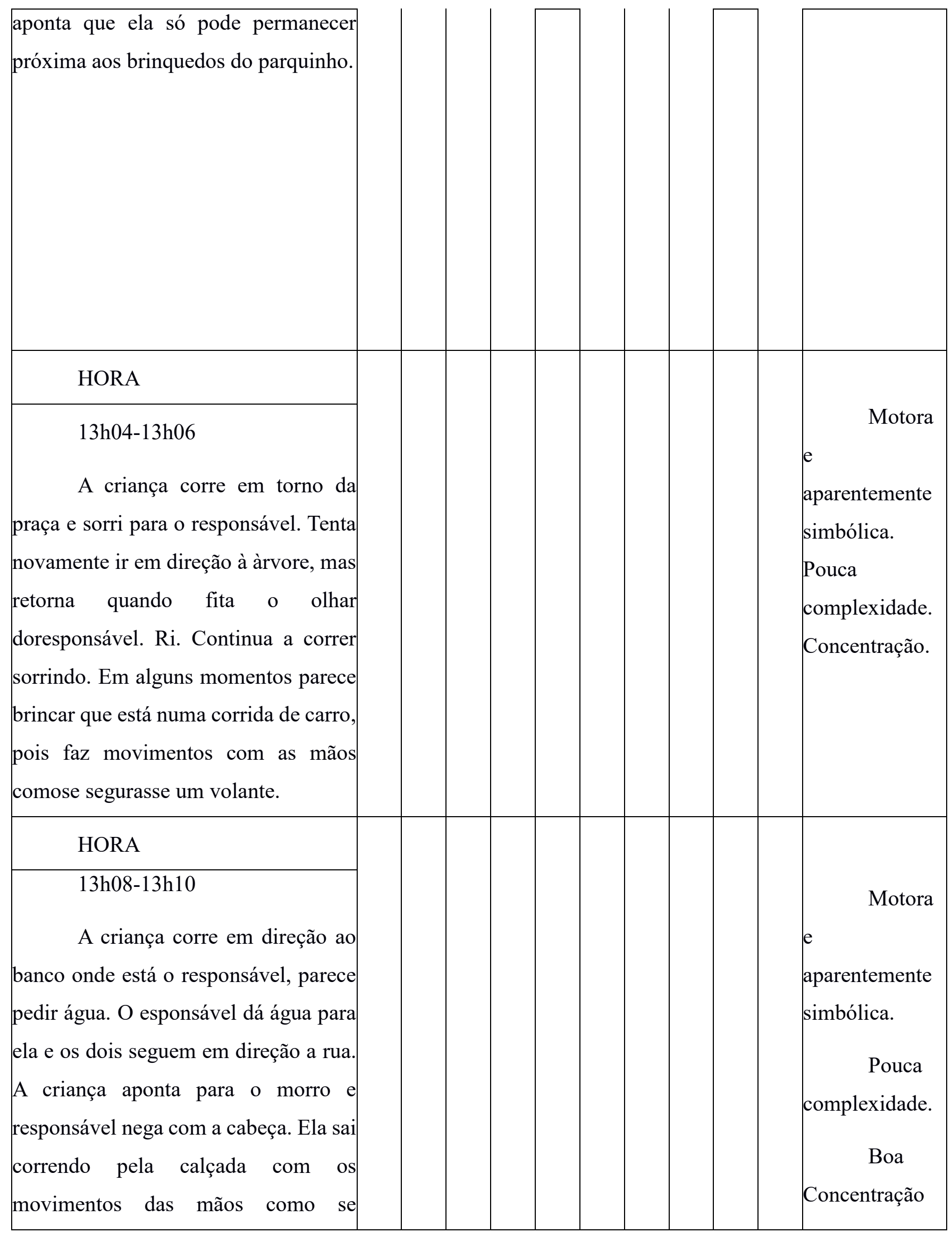


Cadernos CERU, Série 2, Vol. 31, n. 1, jun. 2020

segurasse um volante

$+5|+|+|+|+\mid$


Cadernos CERU, Série 2, Vol. 31, n. 1, jun. 2020

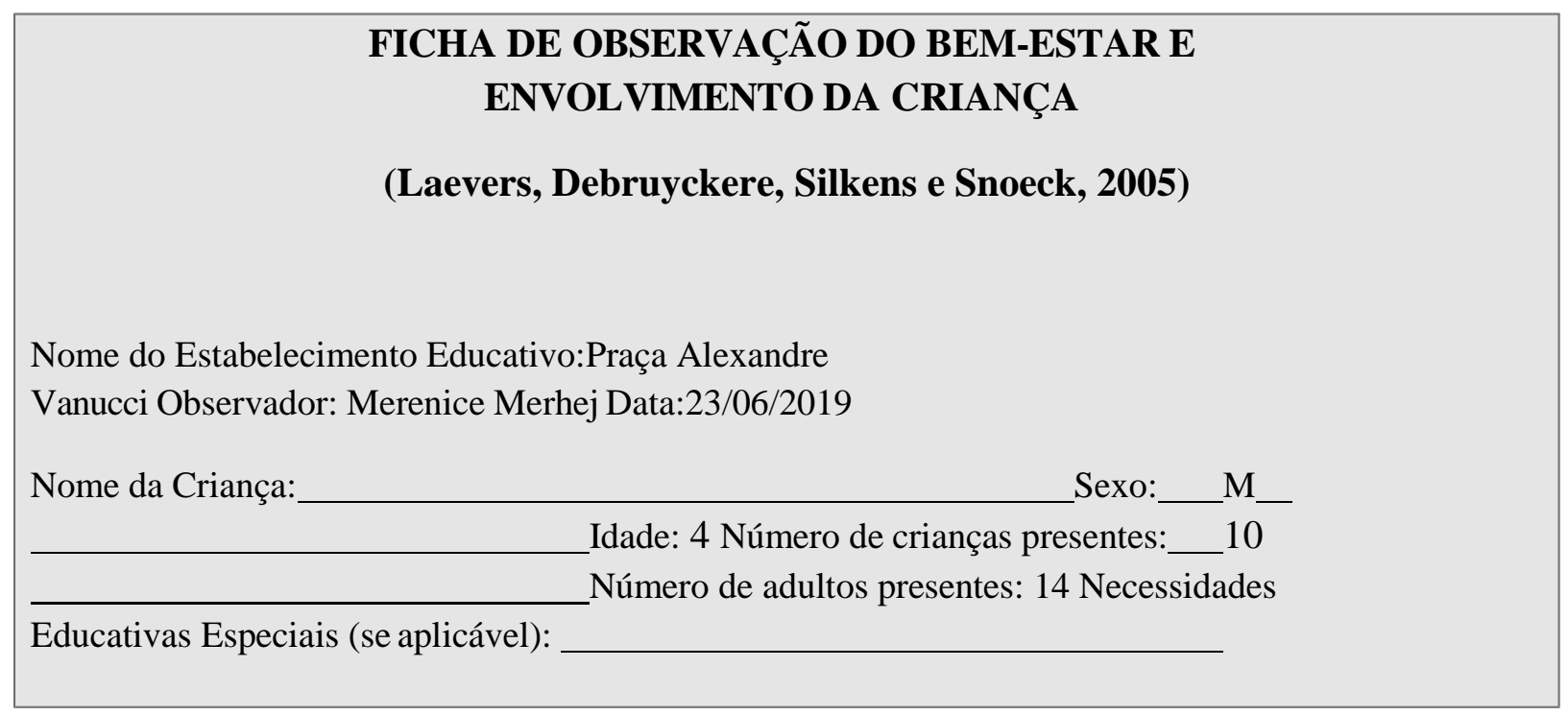

(M) Manhã/ (T) Tarde

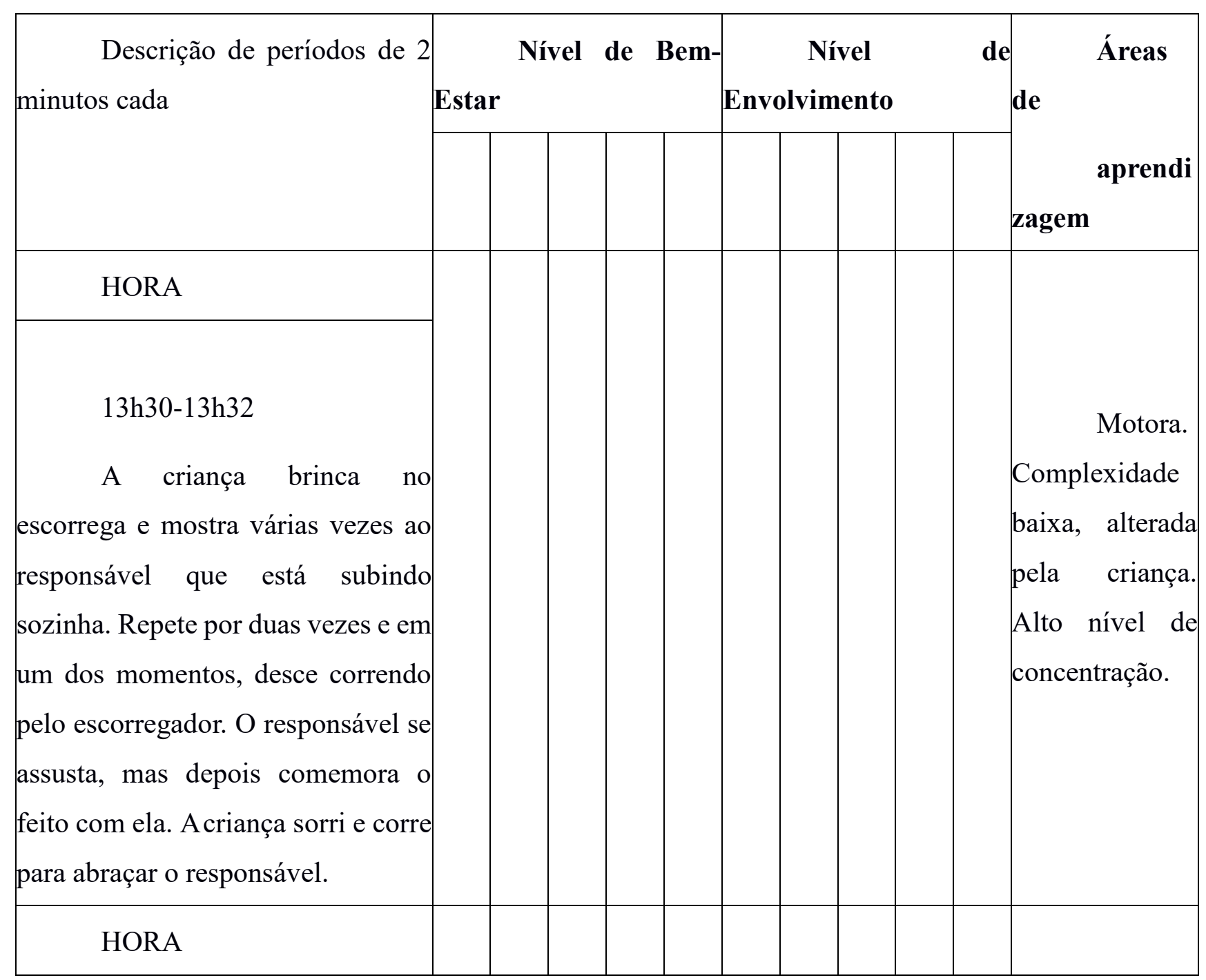


Cadernos CERU, Série 2, Vol. 31, n. 1, jun. 2020

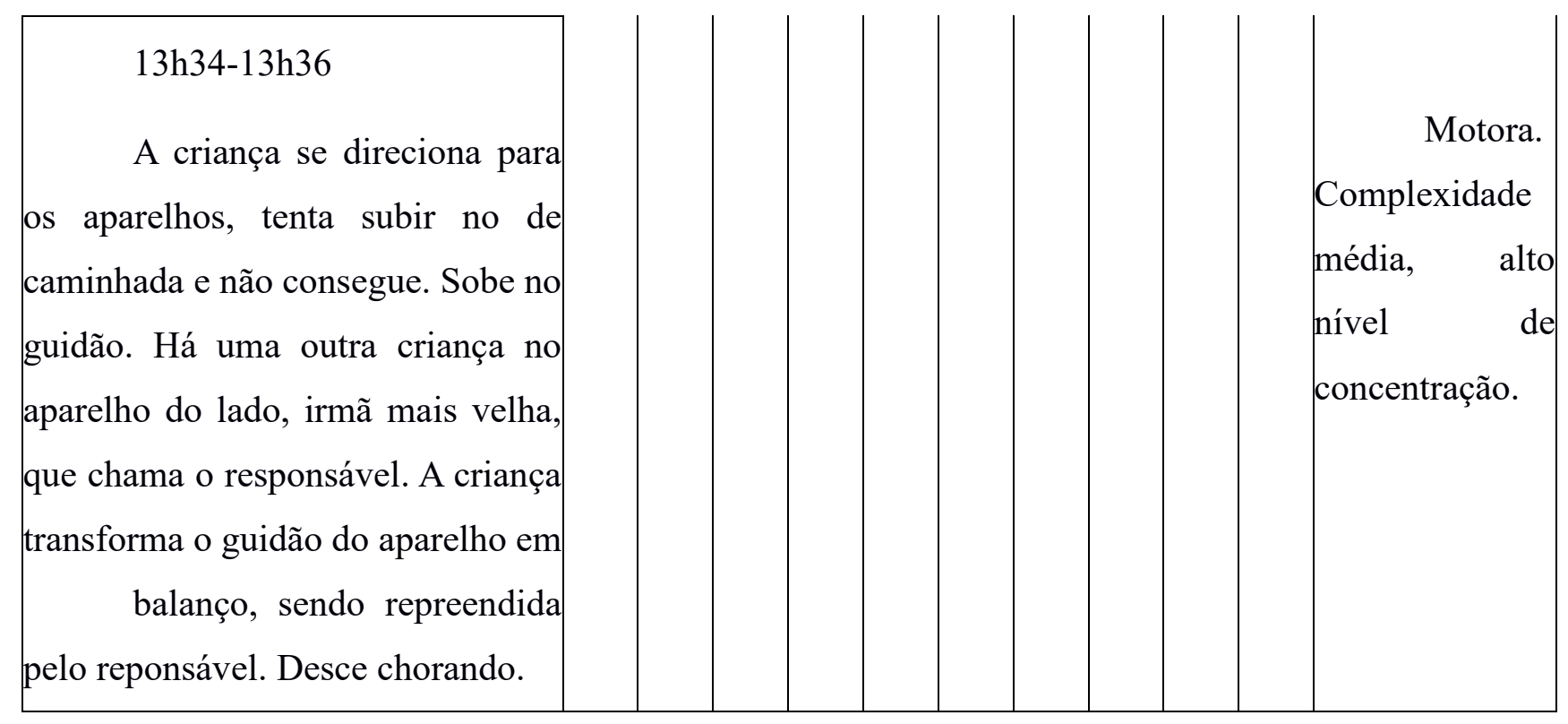




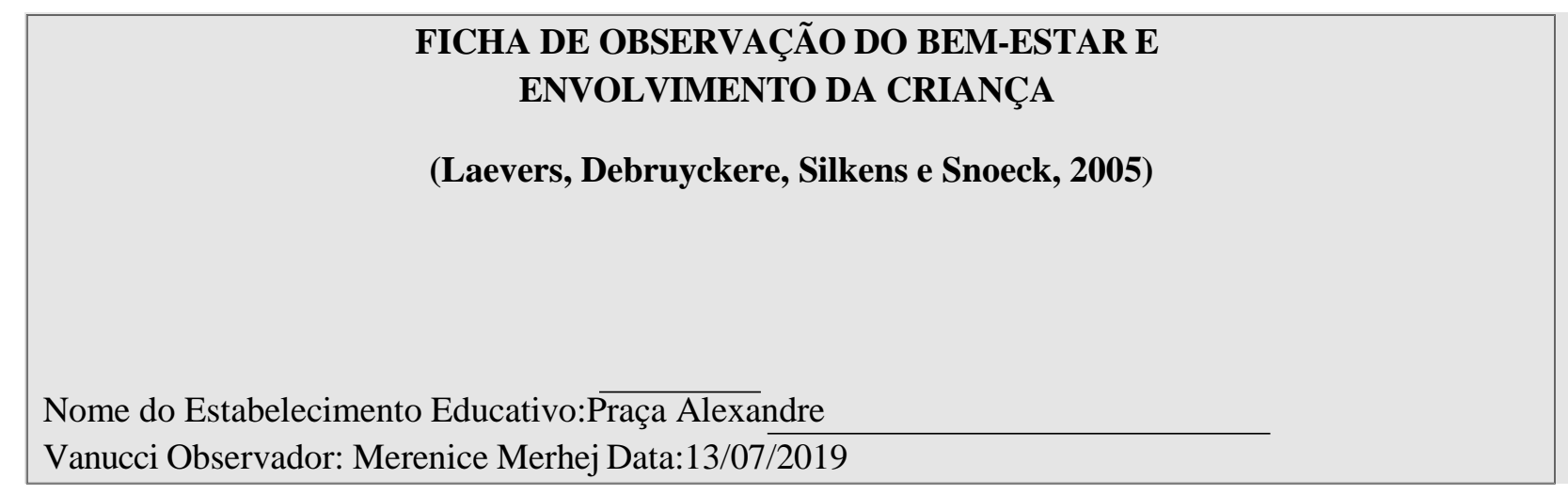

\section{(M) Manhã/ (T) Tarde}

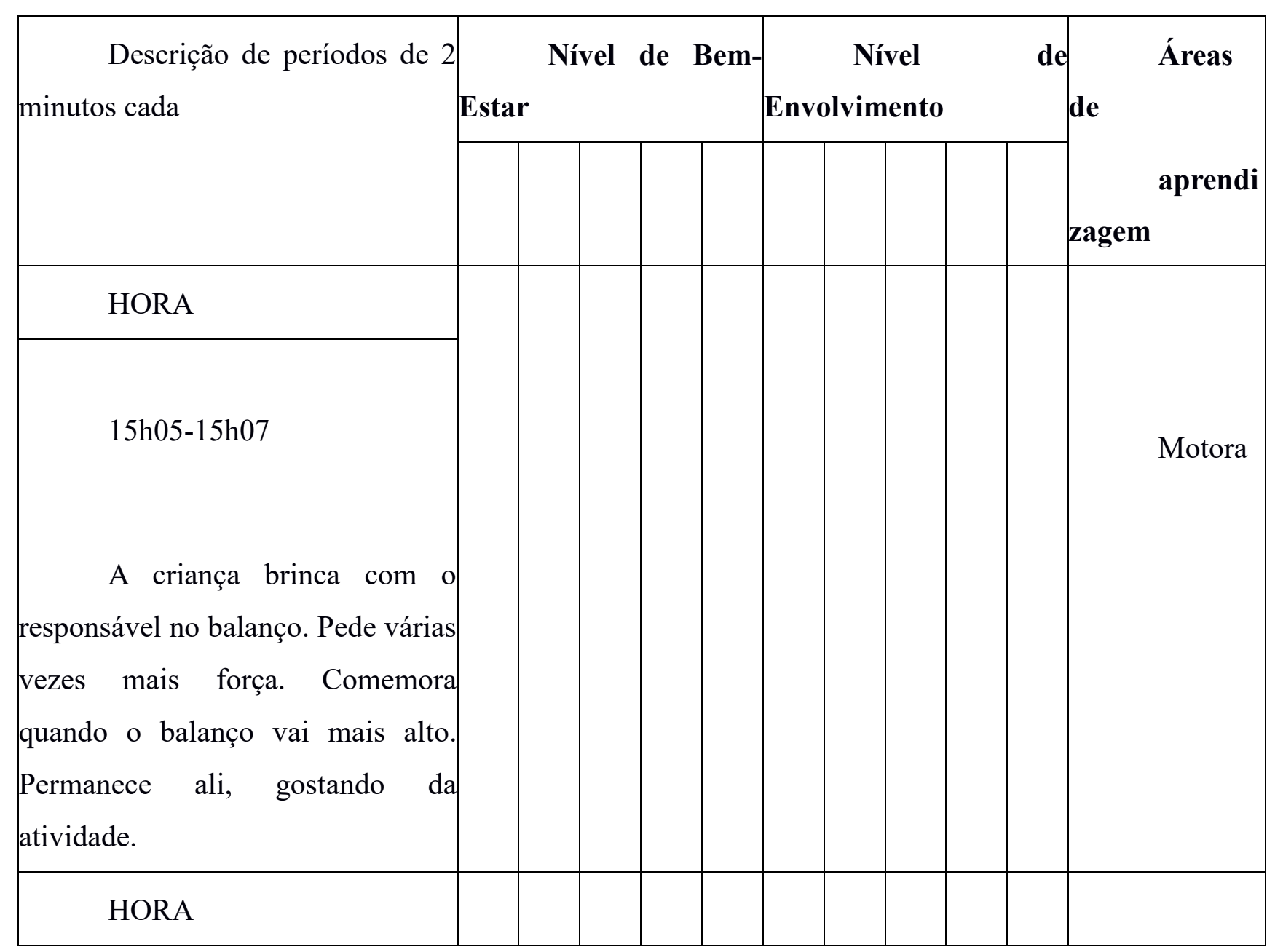


Cadernos CERU, Série 2, Vol. 31, n. 1, jun. 2020

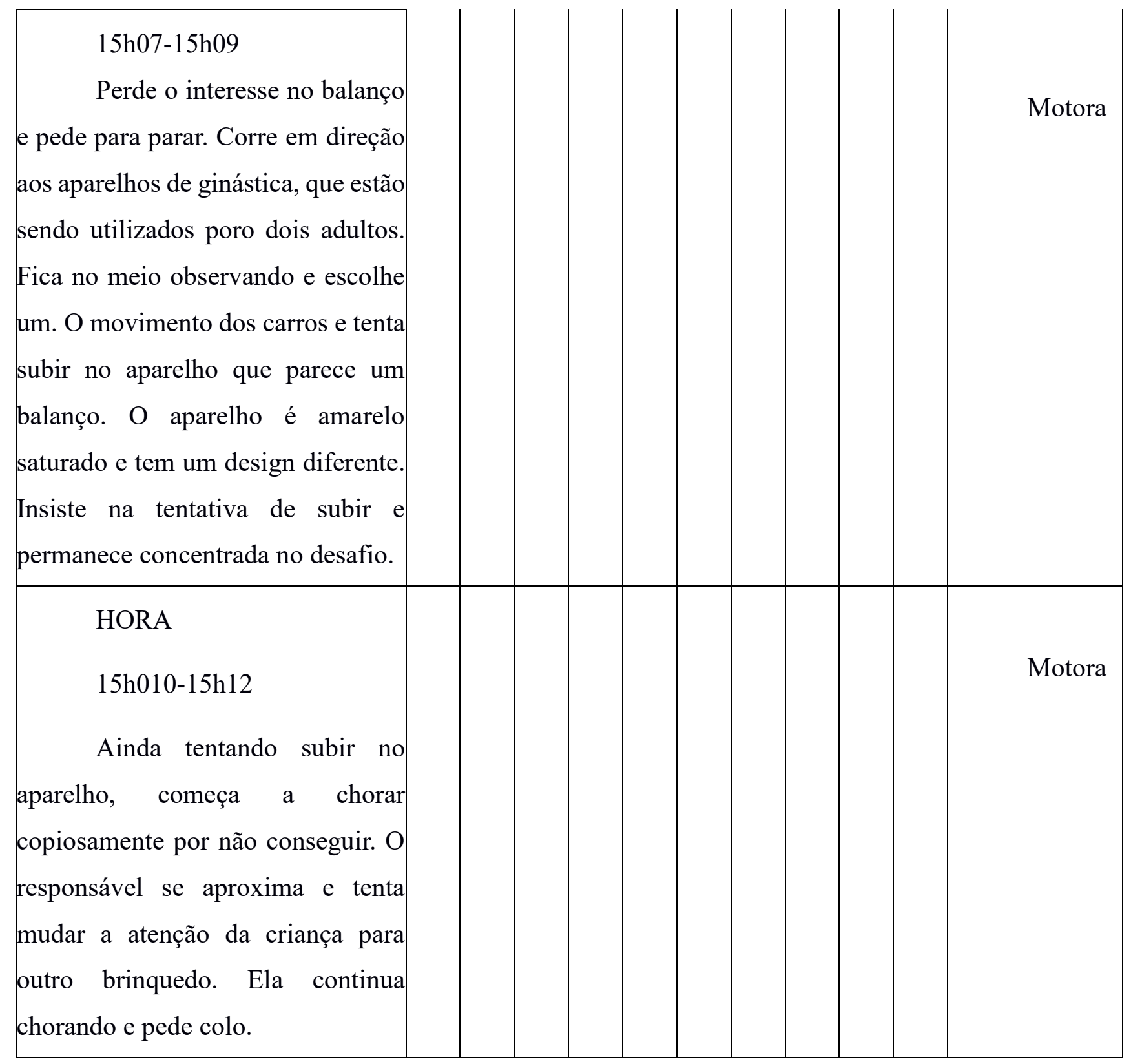




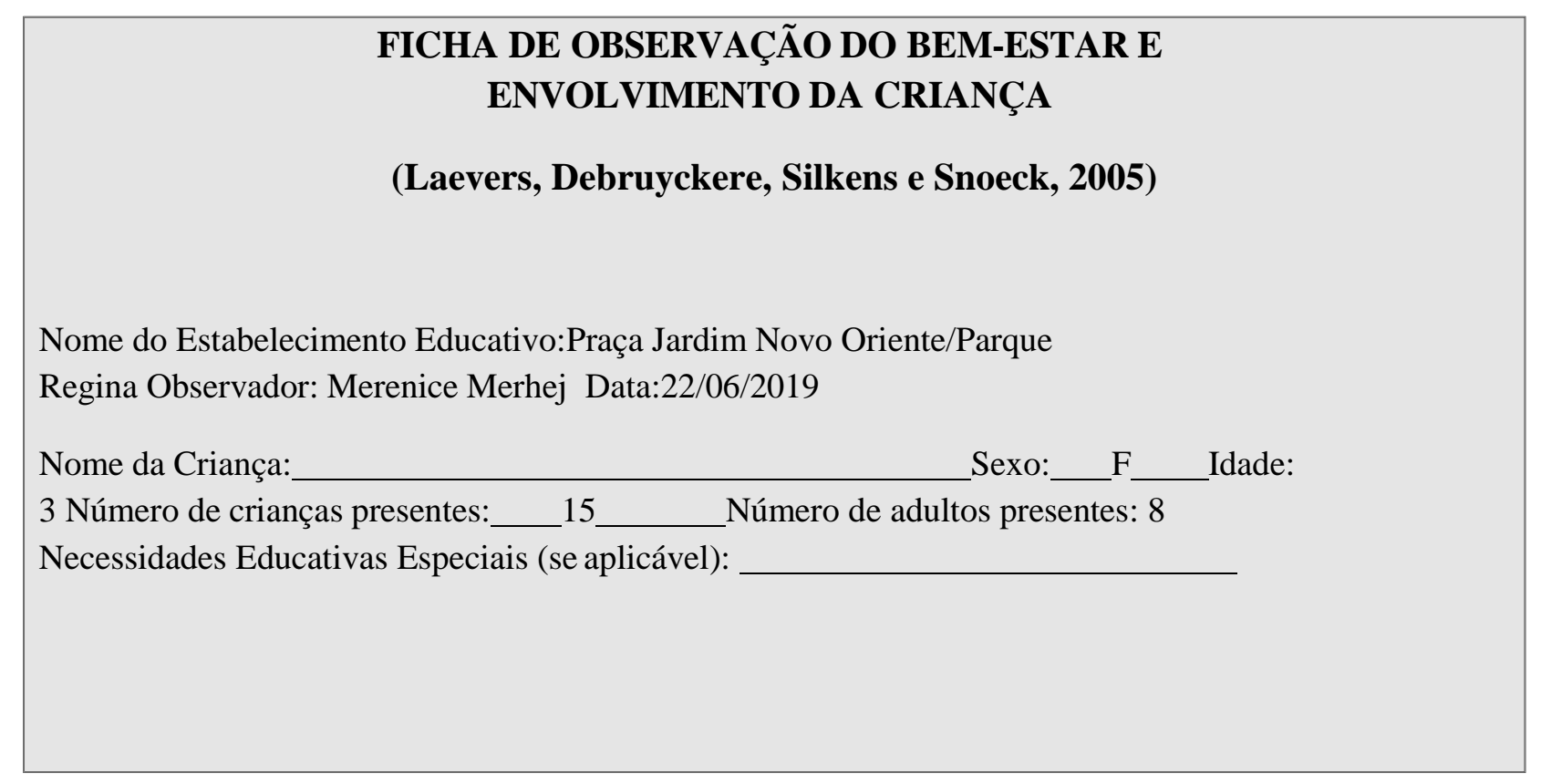

\section{(M) Manhã/ (T) Tarde}

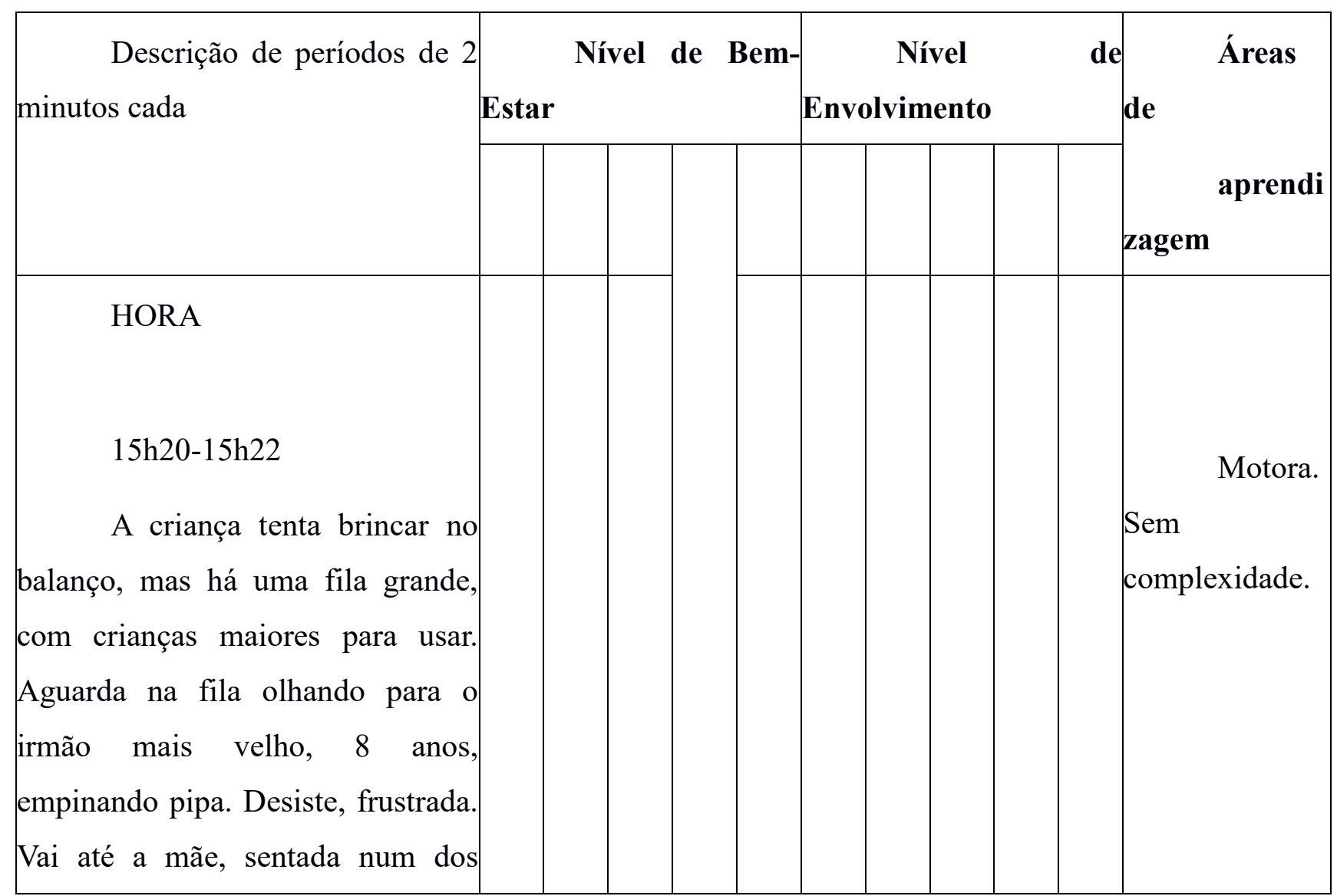


Cadernos CERU, Série 2, Vol. 31, n. 1, jun. 2020

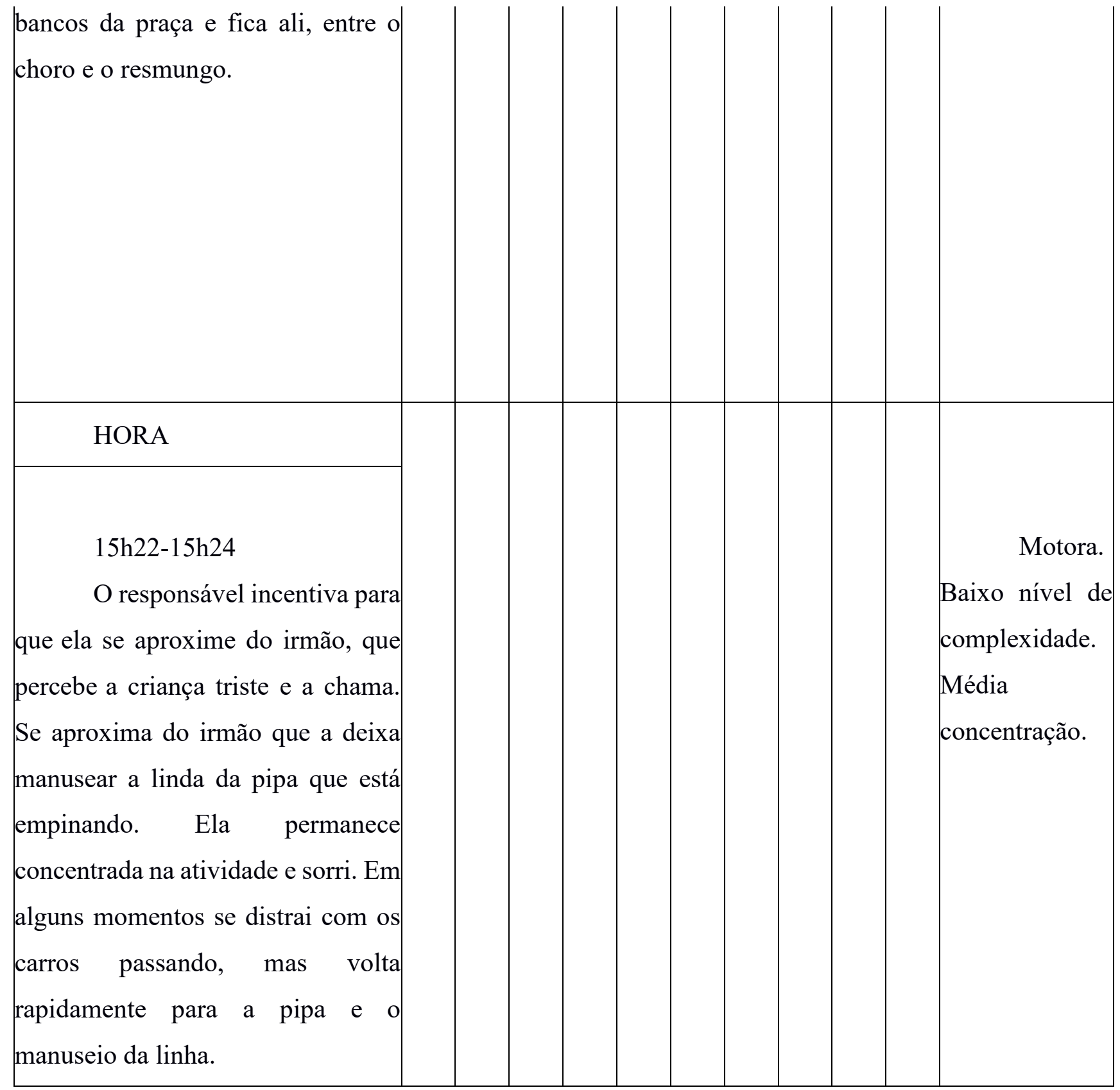




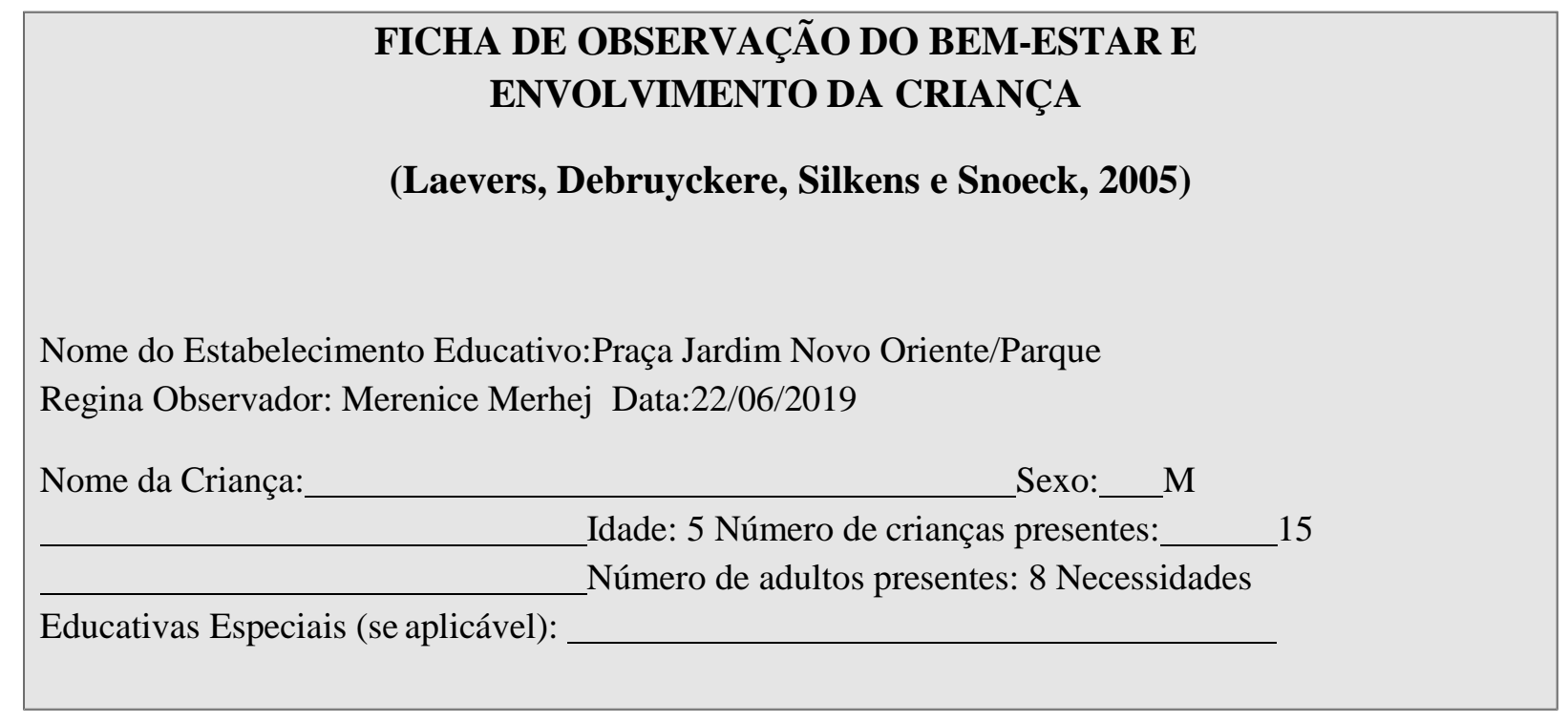

\section{(M) Manhã/ (T) Tarde}

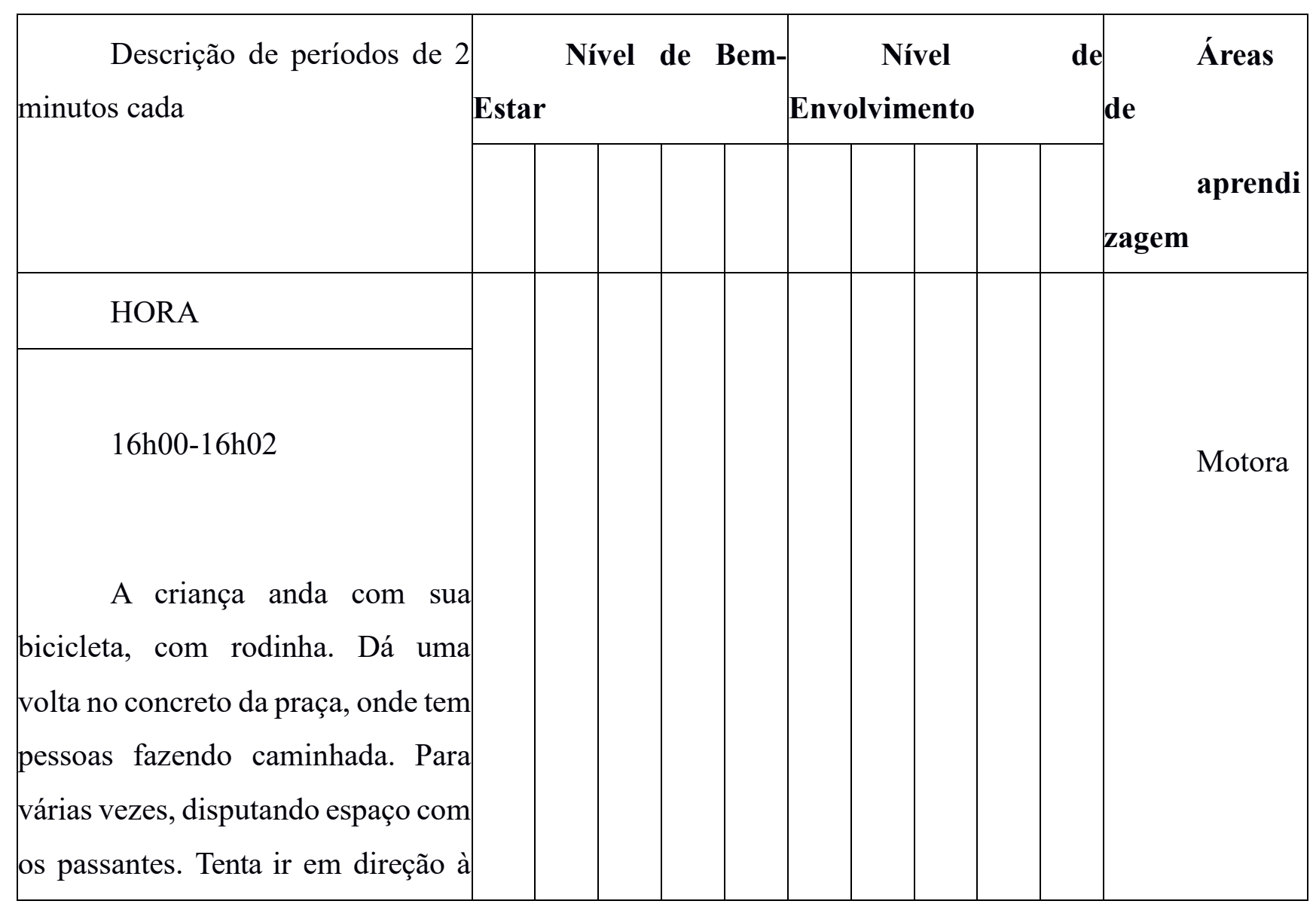


Cadernos CERU, Série 2, Vol. 31, n. 1, jun. 2020

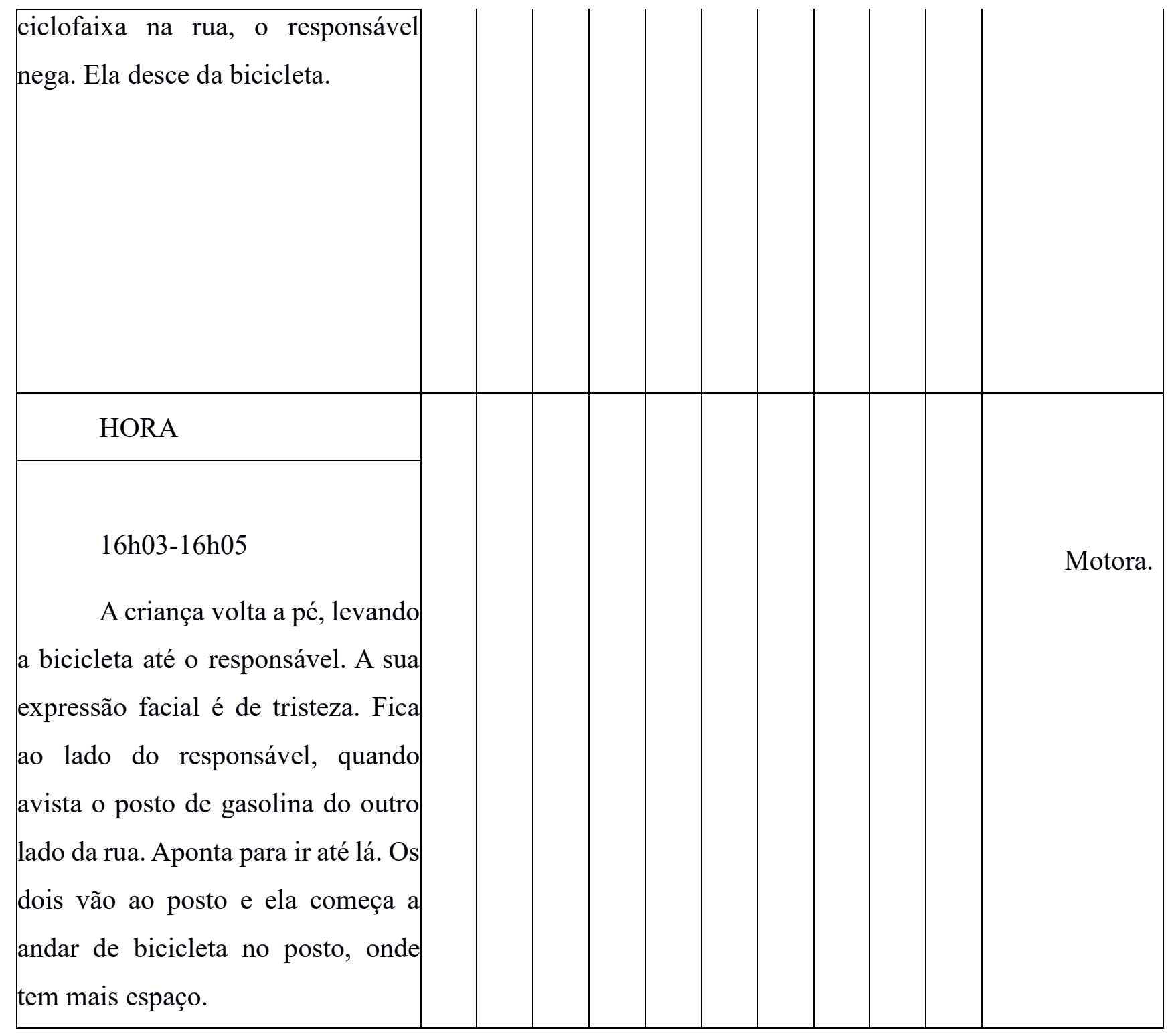


Cadernos CERU, Série 2, Vol. 31, n. 1, jun. 2020

\section{FICHA DE OBSERVAÇÃO DO BEM-ESTAR E ENVOLVIMENTO DA CRIANÇA}

\section{(Laevers, Debruyckere, Silkens e Snoeck, 2005)}

Nome do Estabelecimento Educativo:Praça Jardim Novo Oriente/Parque

Regina Observador: Merenice Merhej Data:22/06/2019

Nome da Criança: Sexo: $F$

Idade: 3 Número de crianças presentes: 15

Número de adultos presentes: 8 Necessidades

Educativas Especiais (se aplicável):

(M) Manhã/ (T) Tarde

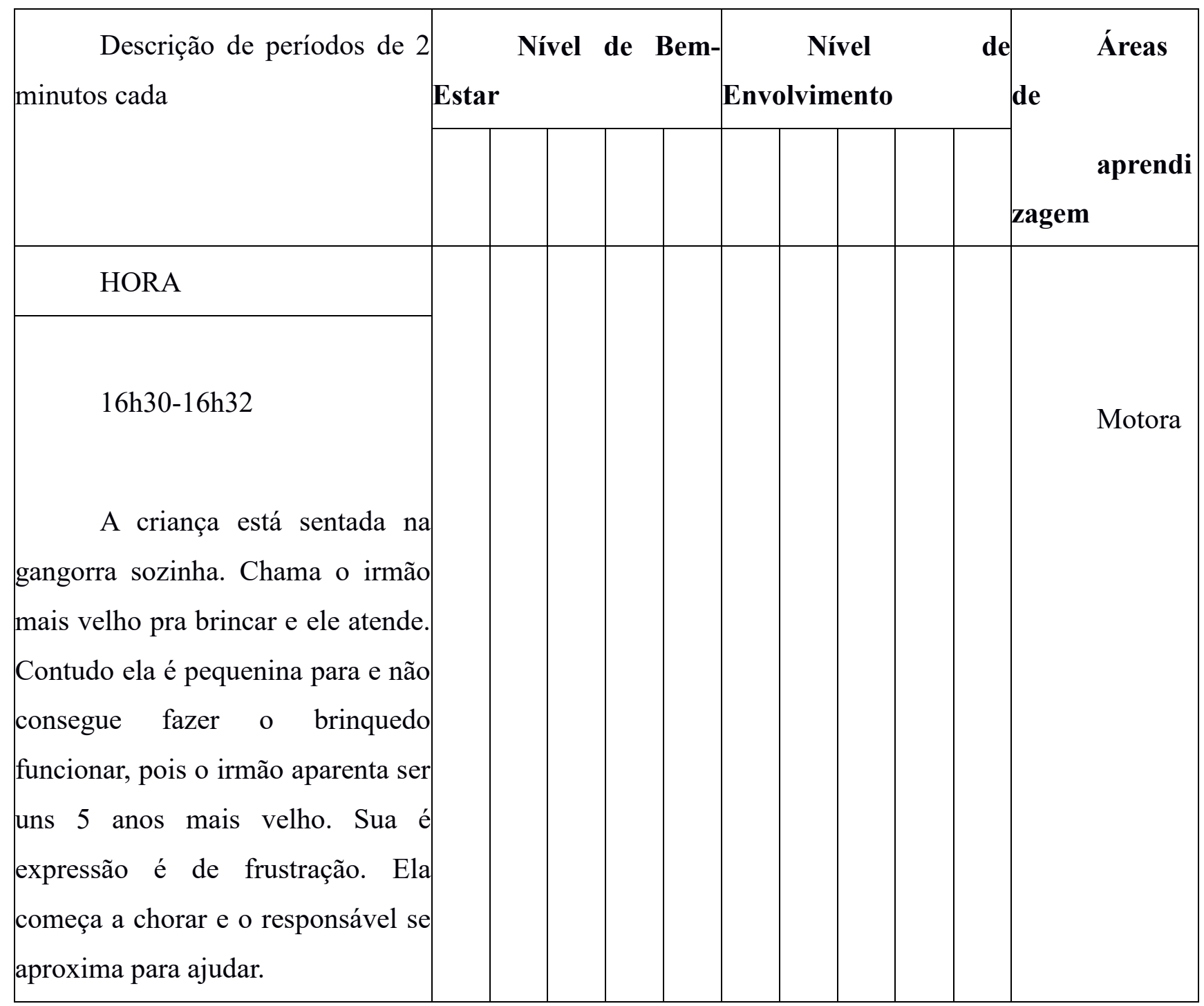


Cadernos CERU, Série 2, Vol. 31, n. 1, jun. 2020

\begin{tabular}{|r|l|l|l|l|l|l|l|}
\hline HORA & \\
16h33-16h35 \\
A criança perde o interesse, \\
levantando os bracinhos para que o \\
responsável a pegue no colo. o \\
responsável pergunta se ela não quer \\
mais brincar e ela faz sinal negativo \\
com a cabeça, abraçando-o \\
fortemente como se não quisesse \\
mais sair de seu colo. Começa a \\
chorar.
\end{tabular}

